\title{
THE RISE AND FALL OF SWEDISH UNEMPLOYMENT
}

\author{
BERTIL HOLMLUND
}

\section{CESIFO WORKING PAPER No. 918}

CATEGORY 4: LABOUR MARKETS

APRIL 2003

Presented at CESifo Conference on Unemployment in Europe,

December 2002

\footnotetext{
An electronic version of the paper may be downloaded

- from the SSRN website: www.SSRN.com

- from the CESifo website: www.CESifo.de
} 


\title{
THE RISE AND FALL OF SWEDISH UNEMPLOYMENT
}

\begin{abstract}
By international standards, unemployment in Sweden remained remarkably low throughout the 1970s and the 1980s. In the early 1990s, however, the unemployment rate skyrocketed and hit double-digit levels. Unemployment remained high for several years but exhibited a marked fall from 1997 and onwards. The paper describes this development and discusses the causes of the rise and fall of unemployment. It is argued that the steep rise in unemployment was mainly the result of a series of adverse macroeconomic shocks, partly self-inflicted by bad policies and partly caused by unfavourable international developments. Institutional factors, such as a trend increase in the generosity of unemployment insurance, caused some secular rise in NAIRU but do not appear as promising explanations of the events of the early 1990s. The fall in unemployment in the late 1990s reflects a combination of favorable macroeconomic conditions and structural factors that may have reduced the NAIRU.
\end{abstract}

JEL Code: E24, J60, J64.

Keywords: unemployment,employment, macroeconomic shocks, labor market institutions.

\author{
Bertil Holmlund \\ Department of Economics \\ Uppsala University \\ Box 513 \\ SE-75120 Uppsala \\ Sweden \\ bertil.holmlund@nek.uu.se
}

The paper was prepared for the Yrjö Jahnsson Foundation and CESifo conference on "Unemployment in Europe: Reasons and Remedies", Munich, 6-7 December 2002. I thank Rainer Fehn and conference participants for useful comments on an earlier draft. Valuable comments from Nils Elvander, Ingemar Hansson, Jens Henriksson, Oskar Nordström Skans, Henry Ohlsson, Donald Storrie and seminar participants at FIEF, Stockholm, are also acknowledged. 


\section{Introduction}

During the 1980s, Swedish labor market performance was widely appreciated as a remarkable success story. Whereas unemployment in Western Europe climbed to double-digit figures, the Swedish unemployment rate remained exceptionally low by international standards. The average unemployment rate during the 1980s was around 2 percent and by the end of the decade it had fallen to 1.5 percent. Employment-to-population rates were also exceptionally high by international standards. In 1990, total employment had risen to 83 percent of the working age population, whereas the average European figure was 61 percent and the OECD average 65 percent. These favorable outcomes were often seen as the result of a combination of coordinated wage bargaining that delivered wage moderation and active labor market policies that facilitated matching between vacancies and unemployed job searchers (see for example Layard et al, 1991).

The rosy picture of outstanding Swedish labor market performance has not fared well during the 1990s. Between 1990 and 1993, unemployment increased from 1.6 percent to 8.2 percent and total employment declined to 73 percent of working age population. For five successive years in the mid-1990s, official unemployment was stuck at around 8 percent whereas extended measures of unemployment reached double-digit figures. The Swedish performance seemed to have converged the European average.

Although the prospects for a sustained labor market improvement appeared remote in the mid1990s, a strong recovery was in fact around the corner. From 1997 and onwards, employment exhibited a marked increase and unemployment fell precipitously. By the end of 2000, unemployment had reached 4 percent of the labor force and it remained fairly constant at this level during 2001 and 2002.

Why did Swedish unemployment rise so sharply in the early 1990s and why did it decline during the end of the decade? Those are the main issues discussed in this paper. It is argued that the steep increase in unemployment in the early 1990s was mainly the result of a series of adverse macroeconomic shocks, partly self-inflicted by bad policies and partly caused by unfavorable international developments. The policy failures date back to the 1970s and include an inability to pursue a sufficiently restrictive aggregate demand policy so as to bring inflation under control. This inflationary bias in policy was especially pronounced in the late 1980s when it was fueled by financial liberalization. 
On the positive side, the inflationary bias of fiscal and monetary policies reflected a firm commitment to maintain full employment. If unemployment approached 3 percent, as it did in the early 1970s, this was considered to be a major policy failure. If it rose above 3 percent, as in the early 1980s, the policy failure was even worse. Although estimates of the NAIRU are fragile, it seems fairly clear that actual unemployment during the late 1980s was well below levels consistent with stable inflation.

Even if macroeconomic shocks explain most of the steep rise in unemployment, other factors have caused some rise in the Swedish NAIRU since the 1960s and throughout the 1980s. A trend increase in the generosity of unemployment insurance is a case in point. During the 1990s, however, unemployment insurance became less generous. Other factors, such as product market deregulations and innovations in wage bargaining, may also have contributed to some decline in equilibrium unemployment in recent years.

We begin in Section 2 by describing the evolution of unemployment, its structure and its dynamic features. We also present some facts about how active labor market policies have responded to the turbulence of the 1990s. Section 3 of the paper discusses the causes of the increase in unemployment. There are a number of suspects, including macroeconomic shocks as well as structural changes that may have affected equilibrium unemployment. Section 4 turns to a discussion of the fall in unemployment during the late 1990s and Section 5 concludes the paper.

\section{The Evolution of Unemployment}

\subsection{The Aggregate Picture}

The Swedish unemployment rate displayed modest fluctuations around an average level of 2 percent during the 1960s, the 1970s and the 1980s. ${ }^{1}$ A weak trend increase in unemployment could be identified, however. The recession of the early 1970s entailed higher unemployment than what was observed during the 1960s. Likewise, the early 1980s witnessed a recession where unemployment approached 4 percent, a level considered as exceptionally high by the

\footnotetext{
${ }^{1}$ The unemployment figures that are used in this paper refer unless stated otherwise to labor force survey data and national definitions. The latter differ slightly from unemployment according to the definitions by the International Labour Organisation (ILO). In particular, students engaged in fulltime job search are classified as unemployed by ILO but as out of the labor force in the national definition. Labor force survey data are not available before the early 1960s. The working age population is generally confined to those aged 16 to 64 .
} 
standards of the 1960s and the 1970s. However, by the end of the 1980s the unemployment rate had reached a decade low of 1.1 percent (June 1989).

The three decades from the early 1960s to the late 1980s also involved sharply rising female participation rates. In 1965, female participation in the labor force stood at 54 percent; in 1989 it had risen to 82 percent. Male participation rates fell only modestly - from 89 to 86 percent between 1965 and 1989 - and the aggregate labor force participation rate thus rose dramatically. Employment increased in tandem with the increase in participation. By the late 1980s, employment-to-population rates stood at 85 and 81 percent for males and females, respectively.

The slump of the early 1990s involved a fall in the level of GDP from peak to trough by 6 percent and produced an unprecedented increase in unemployment. Between 1990 and 1993, unemployment rose from 1.5 percent to 8.2 percent. The increase in unemployment was accompanied by a sharp decline in labor force participation among both men and women. The total decline in employment in the early 1990s amounted to around 500000 persons, or a fall in the employment-to-population rate from 83 percent to 73 percent between 1990 and 1993. Over the period 1993 to 1997, the unemployment rate hovered around 8 percent whereas employment fell slightly (reaching 70.7 percent of population in 1997). However, a strong rebound began in 1997 and involved a rise in GDP growth and employment as well as a substantial fall in unemployment. By 2001 the unemployment rate had fallen to 4 percent and the employment-to-population rate had increased to 75 percent.

The evolution of unemployment according to several measures is displayed in Figure 2.1 and Figure 2.2. The gap between "ILO unemployment" and the national measure in Figure 2.1 consists of full-time students searching for a job. The ILO rate hit 10 percent in 1996 and 1997 and had fallen to 5 percent in 2001. An extended measure of unemployment includes also those "latent job seekers" who are jobless, "willing and able" to work but do not meet the search criteria for being classified as unemployed. ${ }^{2}$ This extended unemployment rate hit 1213 percent in the mid-1990s and had fallen below 7 percent by 2001 .

\footnotetext{
${ }^{2}$ The latent job seeker category comprises also full-time students (including persons in labor market training) that search for employment.
} 
Figure 2.1 Official unemployment (Urate) and ILO unemployment (Urate ILO), 1965-2002. Percent of labor force.

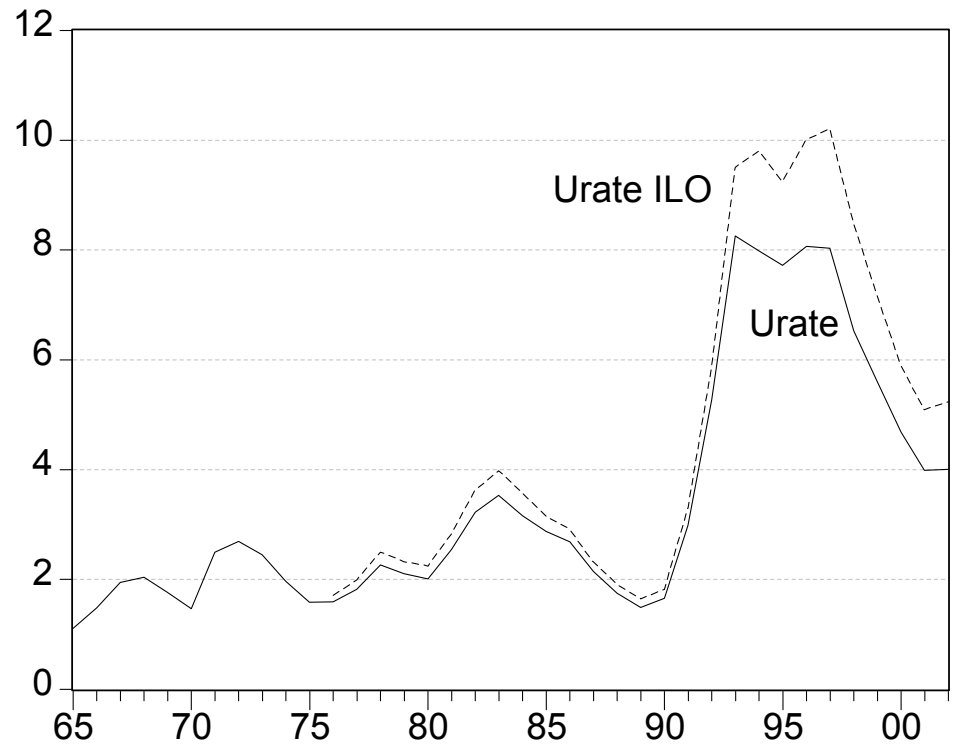

Note: The ILO unemployment rate is based on a labor force measure that includes full-time students engaged in job search.

Source: Labor force surveys, Statistics Sweden.

Figure 2.2 Official unemployment (Urate) and latent job seekers (Latent), percent of labor force. Seasonally adjusted quarterly data 1976-2002.

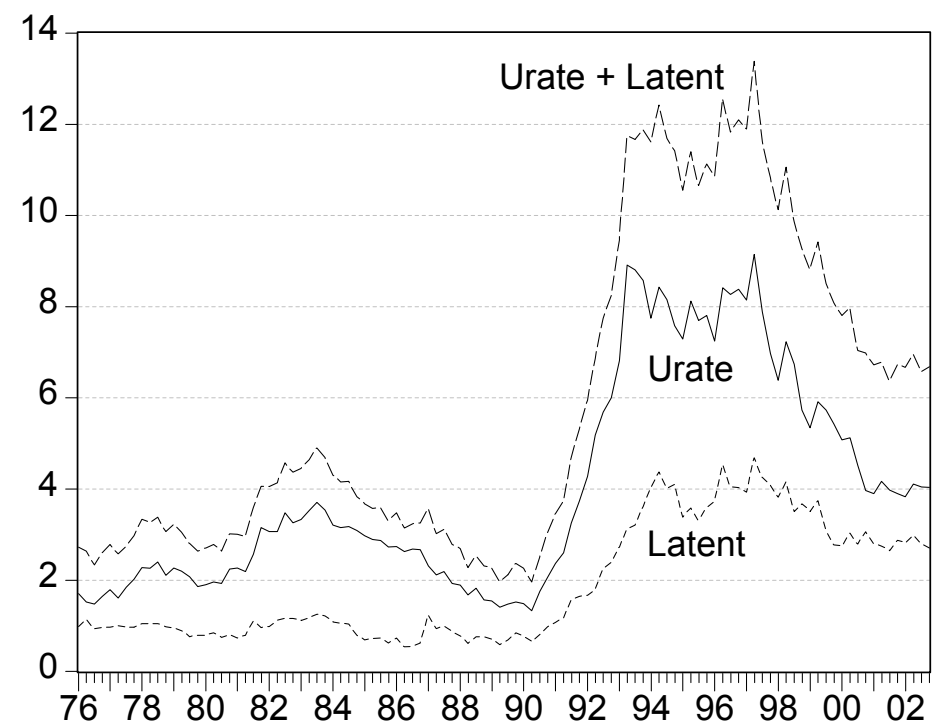

Notes: The labor force is computed as inclusive of latent job seekers. Source: Labor force surveys, Statistics Sweden. 
The average EU unemployment rate stood at around 11 percent in 1995 and had fallen to 8 percent in 2000. The Swedish development is fairly similar to the UK experience over the second half of the 1990s. In both countries, unemployment has roughly been halved. In the Netherlands, another country arguably representing a success story, the decline in unemployment was even more striking; unemployment fell from around 7 percent in the mid 1990s to less than 3 percent in 2000. The Dutch performance stands out even more if one looks at employment growth. Between 1996 and 2000, the employment-to-population rate rose by around 8 percentage points (from 65 to 73 percent). Employment growth in the UK was much more modest over the same period, amounting to a rise in the total employment-topopulation rate by around 2 percentage points. ${ }^{3}$

In summary, the early 1990s saw a rise in Swedish unemployment unprecedented during the post-war period. The recovery that took place from 1997 and onwards has brought about a substantial fall in unemployment as well as an increase in employment. These improvements are not exceptional by European standards, although probably above average. By earlier Swedish standards, however, the current (2002) unemployment rate of 4 percent is about twice as high as the average levels prevailing from the early 1960s and up to the late 1980s. Furthermore, the current overall employment-to-population rate is about 5 percentage points lower than during the late 1980s.

\subsection{The Structure of Unemployment}

The aggregate figures presented above hide considerable diversity in labor market outcomes across demographic and educational groups. However, a basic similarity across groups is that they were all affected by the slump: unemployment rose for all groups, albeit more for some groups than for others. We discuss outcomes for individuals categorized by gender, age, education and immigrant status.

\section{Age and Gender}

Table 2.1 presents unemployment rates by age and gender for some selected years. We also present nonemployment rates, defined as the number of nonemployed (unemployed plus nonparticipants) divided by the relevant population size. For youths, the nonemployment rates

\footnotetext{
${ }^{3}$ See OECD Employment Outlook, various issues. Nickell and van Ours (2000) provide a comprehensive discussion of the evolution of unemployment in the Netherlands and the UK.
} 
are highly sensitive to educational enrollment, including various labor market programs targeted at youths.

The unemployment rate for youths aged 16-24 increased from less than 4 percent to over 15 percent during the first half of the 1990s. In terms of percentage points, this increase was clearly much higher than the average increase. In proportional terms, however, the differences across age groups were fairly small. Roughly speaking, the slump brought about a rise in unemployment for all age groups by a factor of four to five. The overall rise was bigger for men than for women. Note that female unemployment rates were higher than the rates for men in the 1980s (and also earlier); the 1990s have seen a reversal of this ranking.

Turning to nonemployment, the development for youths stands out with a rise by over 20 percentage points between 1990 and 1995. This reflects to a large extent participation in labor market programs as well as increased enrollment in (general) education. The increases in nonemployment among prime-aged and older individuals are of fairly similar magnitudes. Note also that the increase in male nonemployment is slightly bigger than the increase in female nonemployment. The gender difference in nonemployment reached a minimum in 1993, with a difference less than one percentage point.

The recovery has led to a fall in unemployment and nonemployment for all groups. Interestingly, the fall in nonemployment was bigger for older individuals than for prime-aged ones. A nonemployment rate of 30 percent for older men, as in Sweden 2001, is very low by international standards; the OECD average was 40 percent and the EU average around 50 percent in 2000 (see OECD Employment Outlook). A more detailed picture of the pattern of employment by age is shown in Figure 2.3 and confirms the relatively favorable outcomes for older workers. It is remarkable that the employment-to-population rate for the oldest group (60-64) is roughly the same in 2002 as it was in the mid 1980s, despite the slump of the 1990s.

Rising unemployment is clearly only one part of the increase in nonemployment, the other being rising nonparticipation. Table 2.2 provides a decomposition of nonemployment into a few major (self-reported) categories. Participation in labor market programs is not available as a separate category in the labor force surveys. Of the increase in total nonemployment between 1990 and 1995, amounting to 10.9 percentage points, rising unemployment accounts 
for 4.6 percentage points or 42 percent. Unemployment accounts for around half of the total increase in nonemployment among prime-aged and older people, whereas it only accounts for about 20 percent of the increase in youth nonemployment. Activities classified as studies, which include various active labor market programs in addition to general education, account for about 20 percent of the increase in youth nonemployment.

Figure 2.3. Employment-to-population rates by age, 1980-2002.

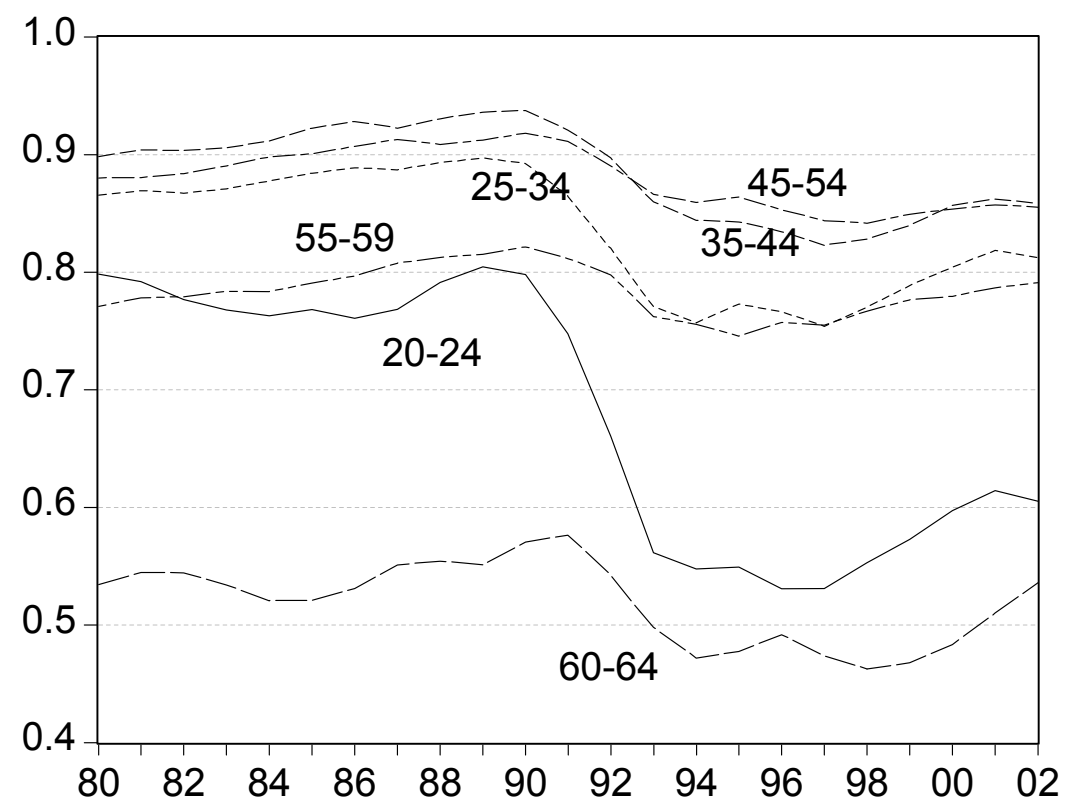

Source: Labor force surveys, Statistics Sweden.

The 1990s have seen a marked increase in enrollment in higher education, which accounts for part of the increase nonemployment. Between 1993 and 1999, the number of undergraduate students rose by 25 percent, which amounts to roughly one percent of overall working age population and almost 10 percent of the population aged 20-24. A major educational drive for low-educated adults (Kunskapslyftet) was initiated in 1997 and encompassed 2 percent of the working age population by the end of that year. 
Table 2.1 Unemployment and nonemployment rates by age and gender (percent).

\begin{tabular}{|c|c|c|c|c|c|c|c|c|c|c|}
\hline & \multicolumn{2}{|c|}{1980} & \multicolumn{2}{|c|}{1985} & \multicolumn{2}{|c|}{1990} & \multicolumn{2}{|c|}{1995} & \multicolumn{2}{|c|}{2001} \\
\hline & $u$ & $n$ & $u$ & $n$ & $u$ & $n$ & $u$ & $n$ & $u$ & $n$ \\
\hline Total & & & & & & & & & & \\
\hline $16-24$ & 5.1 & 32.7 & 5.8 & 37.8 & 3.7 & 34.0 & 15.3 & 57.6 & 8.0 & 52.1 \\
\hline $25-54$ & 1.4 & 11.9 & 1.9 & 9.7 & 1.2 & 8.4 & 6.6 & 17.4 & 3.3 & 15.4 \\
\hline $55-64$ & 1.6 & 34.3 & 4.0 & 35.0 & 1.5 & 30.6 & 7.4 & 38.1 & 4.2 & 33.0 \\
\hline $16-64$ & 2.0 & 20.1 & 2.8 & 19.7 & 1.6 & 16.9 & 7.7 & 27.8 & 4.0 & 24.7 \\
\hline \multicolumn{11}{|l|}{ Men } \\
\hline $16-24$ & 4.5 & 31.7 & 5.8 & 38.2 & 3.8 & 33.9 & 16.7 & 58.2 & 9.1 & 52.7 \\
\hline $25-54$ & 1.1 & 5.7 & 2.0 & 6.7 & 1.3 & 6.5 & 7.2 & 16.0 & 3.5 & 13.3 \\
\hline $55-64$ & 1.6 & 22.6 & 3.5 & 26.7 & 1.3 & 25.6 & 8.4 & 35.6 & 4.6 & 30.4 \\
\hline $16-64$ & 1.7 & 13.8 & 2.8 & 16.4 & 1.7 & 14.8 & 8.5 & 26.5 & 4.3 & 23.0 \\
\hline \multicolumn{11}{|l|}{ Women } \\
\hline $16-24$ & 5.6 & 33.8 & 5.7 & 37.4 & 3.6 & 34.1 & 14.0 & 57.1 & 6.8 & 51.5 \\
\hline $25-54$ & 1.6 & 18.4 & 1.9 & 12.8 & 1.2 & 10.3 & 5.9 & 18.9 & 3.0 & 17.5 \\
\hline $55-64$ & 1.6 & 45.6 & 4.6 & 42.9 & 1.6 & 35.2 & 6.3 & 40.5 & 3.8 & 35.7 \\
\hline $16-64$ & 2.3 & 26.6 & 2.9 & 23.1 & 1.6 & 19.0 & 6.9 & 29.2 & 3.6 & 26.5 \\
\hline
\end{tabular}

Note: The unemployment rate $(u)$ is measured relative to the labor force, the nonemployment rate $(n)$ relative to population.

Source: Labor force surveys, Statistics Sweden. 
Table 2.2 Nonemployment by type of (in)activity, percent of population.

\begin{tabular}{|c|c|c|c|c|c|c|c|c|c|c|c|c|}
\hline & \multicolumn{4}{|c|}{1990} & \multicolumn{4}{|c|}{1995} & \multicolumn{4}{|c|}{2001} \\
\hline & $16-24$ & $25-54$ & $55-64$ & $16-64$ & $16-24$ & $25-54$ & 55-64 & $16-64$ & $16-24$ & $25-54$ & $55-64$ & $16-64$ \\
\hline Unemployed & 2.5 & 1.1 & 1.0 & 1.4 & 7.7 & 5.8 & 4.9 & 6.0 & 4.2 & 2.9 & 3.0 & 3.1 \\
\hline Students & 26.3 & 1.9 & 0.1 & 6.4 & 39.5 & 3.3 & 0.3 & 9.3 & 37.2 & 4.1 & 0.8 & 8.9 \\
\hline $\begin{array}{l}\text { Household } \\
\text { work }\end{array}$ & 1.1 & 1.8 & 5.3 & 2.2 & 1.1 & 1.6 & 2.4 & 1.6 & 0.7 & 1.0 & 0.8 & 0.9 \\
\hline Other & 4.1 & 3.6 & 24.2 & 6.9 & 9.3 & 6.7 & 30.5 & 10.8 & 10.0 & 7.4 & 28.5 & 11.7 \\
\hline $\begin{array}{l}\text { Total } \\
\text { nonemployment }\end{array}$ & 34.0 & 8.4 & 30.6 & 16.9 & 57.6 & 17.4 & 38.1 & 27.8 & 52.1 & 15.4 & 33.0 & 24.7 \\
\hline
\end{tabular}


A significant fraction of nonparticipation involves "inactivity" associated with early retirement, receipt of disability pensions and long-term sickness. Information on these categories is not available on a consistent basis in the labor force surveys. There is nevertheless strong evidence, from the labor force surveys and other sources, that nonparticipation for various disability and sickness-related reasons has increased over the 1990s. The residual category "other" includes, among other things, persons in long-term sickness or with disability pensions. This category rose by 4 percentage points between 1990 and 1995 and accounts for over a third of the increase in total nonemployment. For older workers, the category accounts for over 80 percent of the increase. Note that there is a rise in the "other" group also between 1995 and 2001, despite generally improving labor market conditions.

Labor force survey information on nonparticipation involving long-term sickness or pension receipt (including early retirements) is available for some years. In 1990, around 5 percent of the population belonged to the sickness/pension category. By 2001, this group had increased to 7.7 percent. Register data on the number of persons receiving early retirement benefits reveal an increase in the number of retirees by close to 20 percent between 1990 and 2000, or a rise from 6.8 to 7.8 percent of the working age population (according to data from the National Social Insurance Board).

The rules pertaining to early retirements have undergone several changes since the early 1990s. The basic qualification rule is based on health conditions. However, it has also been possible for older workers (aged 60-64) to qualify for early retirement pension for labor market reasons, i.e., difficulties of finding a job. Before October 1991, labor market reason could be a sufficient condition. From October 1991 and through January 1997, it was possible to qualify for labor market reasons if certain health conditions were also met. From February 1997, labor market reasons are no longer part of the eligibility conditions. There have also been changes in the rules concerning health conditions. A reform in 1993 made the qualification criteria more stringent. These rules have been slightly moderated by new legislation in place from 1999 and onwards.

The bottom line of all this is that the rules pertaining to sickness benefits, early retirements and disability pensions are likely to have important implications for how labor market shocks affect nonemployment in general, and nonparticipation in particular. A reasonable conjecture 
is that even transitory adverse shocks can have permanent effects on nonemployment if the rules favor labor force withdrawals.

\section{Education}

It is a general phenomenon that unemployment is higher for those with relatively low education than for those with higher education. Sweden is no exception in this regard. Table 2.3 shows unemployment and nonemployment rates by educational categories.

Unemployment rates for those with low education are roughly two to three times as high as unemployment among those with university education. The increase in unemployment during the early 1990s affected all education groups. Unemployment rates increased for all education categories by a factor of five to six.

\section{Immigrants}

Over 10 percent of the total population currently living in Sweden was born abroad. Around 6 percent of the working age population in 2001 had a foreign citizenship, whereas the share of foreigners in the labor force was around 5 percent. Unemployment among immigrants is generally higher, sometimes dramatically higher, than unemployment among native Swedes. Table 2.4 gives some data on unemployment and nonemployment rates for foreigners and for the whole labor force. ${ }^{4}$ Unemployment and nonemployment among immigrants vary tremendously by country of origin. Among non-Nordic citizens, the unemployment rate rose from 5 to 30 percent between 1990 and 1995, whereas nonemployment rose from 34 to 64 percent during the same period.

The labor market recovery has led to substantial reductions in nonemployment among immigrants. This is confirmed in detail in a recent study by Nelander and Goding (2003). For example, the unemployment rate fell from 41 to 10 percent between 1997 and 2002 among non-European men with less than ten years of residence in Sweden.

\footnotetext{
${ }^{4}$ The regular labor force surveys contain no information on unemployment among immigrants with Swedish citizenship.
} 
Table 2.3 Unemployment and nonemployment by education, age 25-54 (percent).

\begin{tabular}{|c|c|c|c|c|c|c|c|c|c|c|}
\hline & \multicolumn{2}{|c|}{1980} & \multicolumn{2}{|c|}{1985} & \multicolumn{2}{|c|}{1990} & \multicolumn{2}{|c|}{1995} & \multicolumn{2}{|c|}{2001} \\
\hline & $u$ & $n$ & $u$ & $n$ & $u$ & $n$ & $u$ & $n$ & $u$ & $n$ \\
\hline Compulsory & 2.0 & 16.0 & 3.1 & 15.5 & 1.5 & 9.4 & 8.7 & 18.7 & 4.7 & 24.1 \\
\hline High school & 1.2 & 9.6 & 2.0 & 9.1 & 1.3 & 6.4 & 7.5 & 15.5 & 3.6 & 14.7 \\
\hline University & 0.7 & 6.1 & 1.0 & 4.2 & 0.8 & 4.6 & 3.7 & 10.0 & 2.2 & 11.6 \\
\hline
\end{tabular}

Note: The unemployment rate $(u)$ is measured relative to the labor force, the nonemployment rate $(n)$ relative to population.

Source: Labor force surveys, Statistics Sweden.

Table 2.4 Unemployment and nonemployment among foreign citizens.

\begin{tabular}{l|cc|cc|cc}
\hline & \multicolumn{2}{|c|}{$\mathbf{1 9 9 0}$} & \multicolumn{2}{c|}{$\mathbf{1 9 9 5}$} & \multicolumn{2}{c}{$\mathbf{2 0 0 1}$} \\
& $u$ & $n$ & $u$ & $n$ & & \\
& & & & & & \\
Nordic & 2.5 & 21.2 & 12.2 & 37.3 & 6.6 & 35.6 \\
Other & 5.0 & 33.8 & 30.0 & 64.2 & 13.0 & 46.3 \\
Total foreign & 3.9 & 28.5 & 22.7 & 55.3 & 10.6 & 42.6 \\
$\begin{array}{l}\text { Total } \\
\text { population }\end{array}$ & 1.6 & 16.9 & 7.7 & 27.8 & 4.0 & 24.7 \\
\hline
\end{tabular}

Note: The unemployment rate $(u)$ is measured relative to the labor force, the nonemployment rate $(n)$ relative to population.

Source: Labor force surveys, Statistics Sweden. 


\subsection{The Dynamics of Unemployment}

\section{Inflow and Duration}

Although Swedish unemployment changed relatively little over the period up until the early 1990 s, the average duration of unemployment spells showed a trend increase. In the late 1960s, the average duration of (completed) unemployment spells hovered around 7 weeks; by the mid-1980s, the average duration had increased to 16 weeks. Since unemployment did not change much, it follows that unemployment inflow exhibited a substantial trend decline between the 1960s and the 1980s; see Table 2.5. The slump of the 1990s has completely reversed the trend decline in unemployment inflow. The inflow rate tripled in the early 1990s and has shown only a modest decline during the recovery in the late 1990s. In fact, most of the increase in unemployment can be accounted for by a rise in the inflow rather than by a rise in duration.

Table 2.5 Unemployment inflow and unemployment duration, age 16-64.

\begin{tabular}{cccc} 
& $u$ & $f$ & $D$ \\
$1965-1969$ & 1.8 & 0.27 & 6.8 \\
$1970-1974$ & 2.2 & 0.19 & 11.5 \\
$1975-1979$ & 1.9 & 0.17 & 11.5 \\
$1980-1984$ & 2.9 & 0.19 & 15.5 \\
$1985-1986$ & 2.7 & 0.17 & 15.5 \\
$1987-1988$ & 1.8 & 0.12 & 14.5 \\
$1989-1990$ & 1.5 & 0.10 & 13.8 \\
$1991-1992$ & 3.7 & 0.18 & 20.6 \\
$1993-1995$ & 8.0 & 0.34 & 23.5 \\
$1996-1998$ & 7.5 & 0.31 & 24.2 \\
$1999-2001$ & 4.7 & 0.30 & 15.9 \\
----19 & & & \\
\hline
\end{tabular}

Notes: $u$ is the unemployment rate (percent), $f$ the weekly inflow into unemployment as percent of the labor force, and $D$ the average duration of completed spells of unemployment. $D$ is obtained from the steady state relationship $u=f \cdot D$.

Source: Computations based on data on $u$ and $f$ from the labor force surveys, Statistics Sweden.

It should be kept in mind that labor force exits account for a considerable share of exits from unemployment. During the 1990s, this share accounted for some 40 percent according to the panels of the labor force surveys (Holmund and Storrie, 2001). Register data from the 
employment offices indicate a labor force withdrawal share of around 50 percent (Carling et al, 2001). Labor market programs account for a substantial fraction of the labor force withdrawals. The average duration of joblessness is thus substantially higher than the average duration of (open) unemployment spells. ${ }^{5}$

The panel structure of the labor force surveys makes it possible to measure labor market flows and compute transition rates. ${ }^{6}$ Figure 2.4 shows job finding rates for unemployed workers (UE) as well as job loss rates, i.e., transition rates from employment to unemployment (EU). The steep rise in unemployment during the first years of the 1990s was associated with both a rise in the probability of job loss and a decline in the probability of job finding. Likewise, the recovery during the late 1990s involved marked improvements in job finding rates and reductions in the risk of entering unemployment.

The increase in unemployment inflow is in part also driven by a steep increase in the inflow from nonparticipation. The mere fact that the size of the pool of nonparticipants is much larger in the slump contributes to this development. In addition, the data reveal some increase in the probability of entering unemployment from nonparticipation; see Figure 2.5. The pattern is as expected: the worse the labor market conditions are, the lower the probability of making a "successful" labor market entry.

All in all, the data suggest that the main "mechanical" cause of the rise in Swedish unemployment is the dramatic increase in unemployment inflow that took place in the early 1990s. This development coincided with a steep increase in job destruction, as is revealed in studies by Andersson (1999), Persson (1999) and Arai and Heyman (2002); this is bound to have triggered a rise in the inflow from employment. Those studies also indicate a modest decline in job creation in the early 1990s, something that probably reinforced the rise in unemployment inflow by making it generally more difficult for workers to locate a (new) job without experiencing unemployment.

\footnotetext{
${ }^{5}$ The importance of labor force exits is certainly not a unique Swedish phenomenon driven exclusively by active labor market programs. For example, data on US labor force transitions reported in Clark and Summers (1979) reveal that almost half of all unemployment spells ended by labor force withdrawal.

${ }^{6}$ Respondents remain in the survey for two years and are interviewed every third month. Holmlund and Vejsiu (2001) contain a detailed presentation of the aggregate features of these flow data.
} 
Figure 2.4 Job finding rates (UE) and job loss rates (EU) 1987-2002.

Seasonally adjusted data.

UE

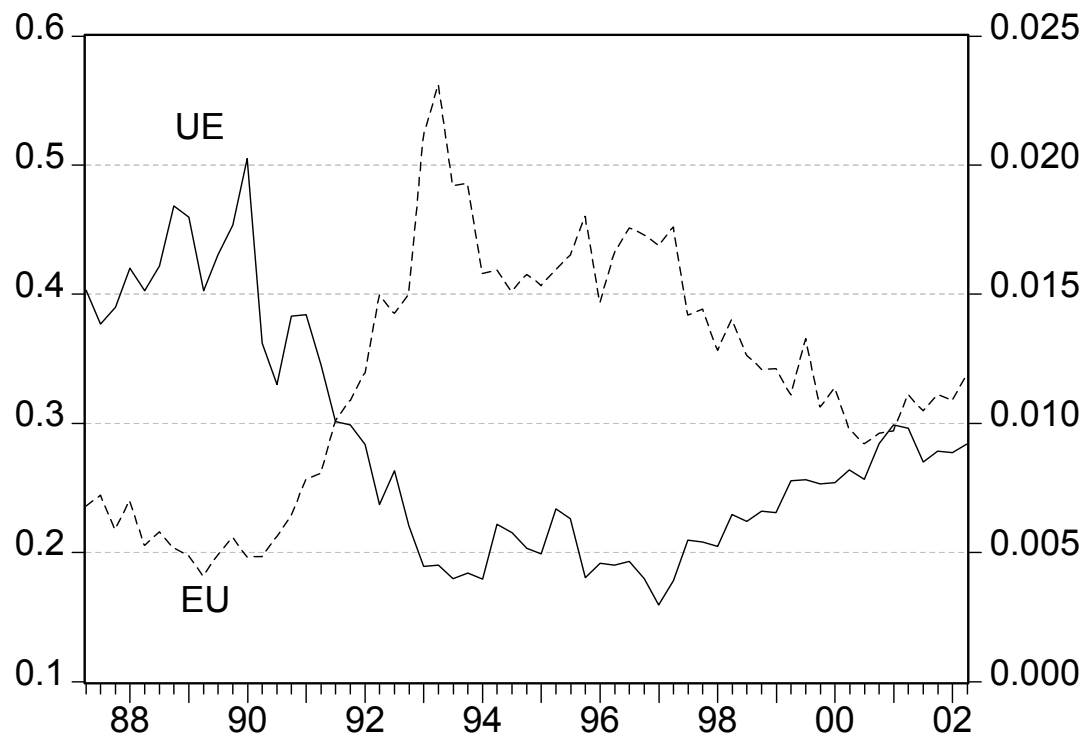

Source: The transition rates are computed from the quarterly panels of the labor force surveys.

Figure 2.5 Transitions between unemployment (U) and out of the labor force (O) 1987-2002. Seasonally adjusted data.

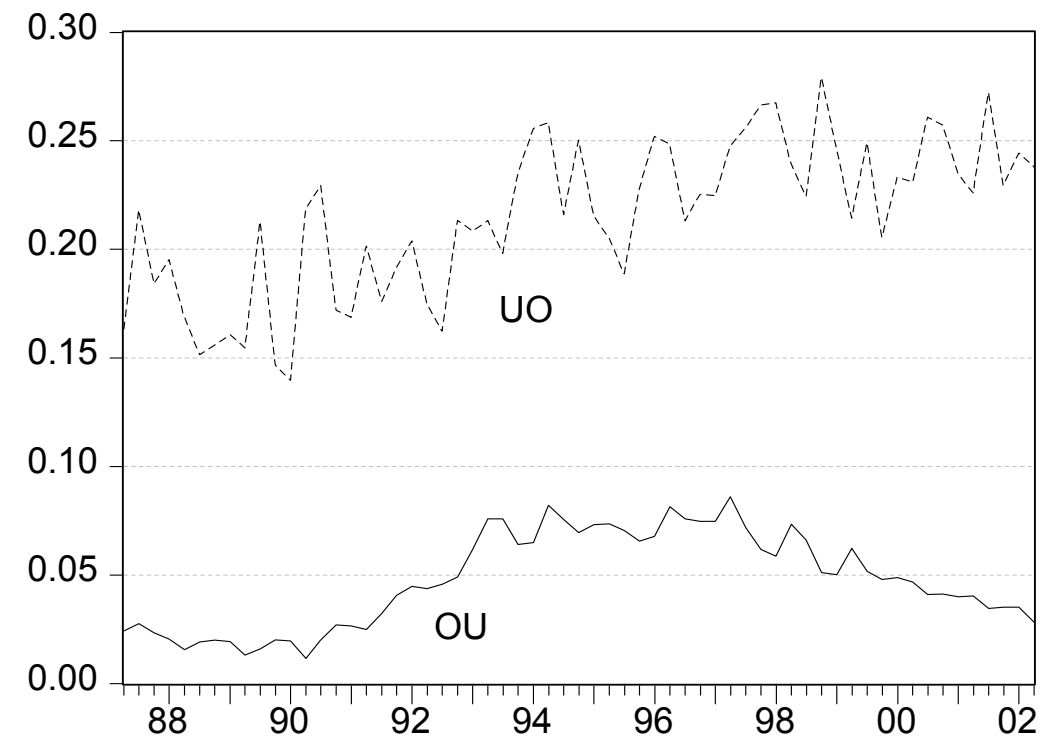

Source: The transition rates are computed from the quarterly panels of the labor force surveys.

\section{Job Finding by Elapsed Duration}

To what extent did the labor market recovery benefit short-term and long-term unemployed?

We take a brief look at this issue by means of data from the public employment offices.

Figure 2.6 shows job finding rates among (“openly") unemployed individuals with varying 
lengths of elapsed duration of joblessness. Duration is measured as time registered at the employment office, irrespective of whether registration time has been spent in open unemployment or in a labor market program. It is notable that the recovery is associated with increased job finding among all duration categories. The rising economic tides could apparently lift out of joblessness also those who had remained there for a very long time.

Figure 2.6 Job finding per month by elapsed duration of joblessness.

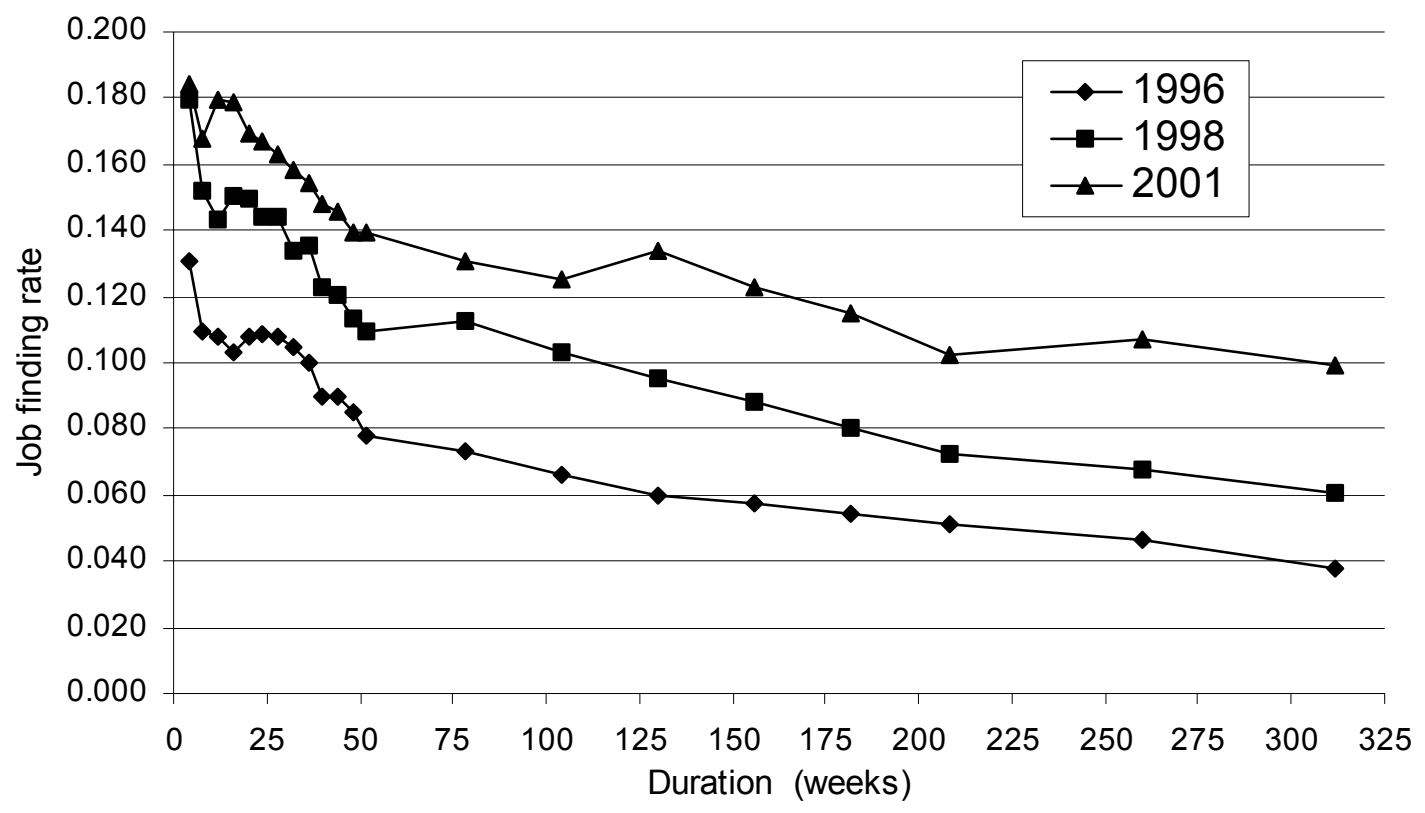

Note: Elapsed duration in joblessness includes open unemployment as well as participation in active labor market programs.

Source: Computations by Anders Harkman, the National Labor Market Board.

\subsection{Active Labor Market Policies}

In an international perspective, Sweden stands out as a country that spends large resources on active labor market policy (ALMP). The policy has a long history. Two trade union economists, Gösta Rehn and Rudolf Meidner, laid out the intellectual foundations in the late 1940s. To them, ALMP was an integral part of a program emphasizing full employment, "solidarity" wage policy and rapid structural change. The key purpose of ALMP was to facilitate productivity-enhancing sectoral labor reallocation. This emphasis on labor reallocation and structural change called for mobility subsidies, employment services to improve matching, and manpower training. ALMP as practiced in Sweden over the past couple of decades has also involved various forms of subsidized employment. Those have traditionally taken the form of "relief jobs" (temporary public jobs). In recent years, relief jobs have disappeared and other recruitment subsidies have been introduced. For example, 
subsidies are paid to employers that hire long-term unemployed (with the going wage paid to those hired). Subsidized employment also includes subsidies to unemployed individuals that wish to start their own businesses.

ALMP-volumes have been gradually expanded from the early 1960s and onwards. By the late 1970s, the number of participants in ALMPs had increased to 2 percent relative to the labor force. ${ }^{7}$ These programs mainly consisted of manpower training and relief jobs. As is clear from Figure 2.7, ALMPs were markedly countercyclical, rising in recessions and falling in booms. This countercyclical pattern was especially pronounced for relief jobs. ${ }^{8}$

Figure 2.7 The number of participants in active labor market programs, percent relative to the labor force 1965-2002.

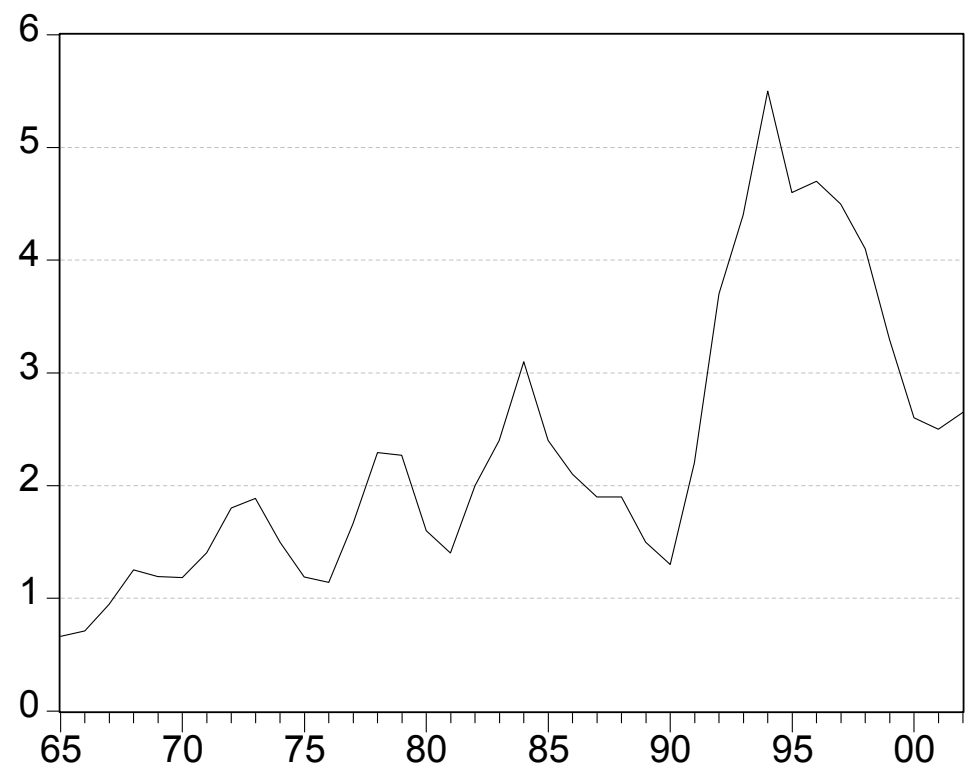

Sources: The National Labor Market Board (programs) and Statistics Sweden (labor force).

The 1990s have seen a large number of new programs, often targeted at unemployed youths. The slump in the early 1990 s was initially met by a steep increase in the volume of training programs, later to be followed by an expansion of subsidized employment and "youth practice" programs. The high rate of policy innovations in this area reflects to some degree a re-labeling of existing types of programs rather than substantive news. Be that as it may, it is plausible that the extensive ALMP measures have lowered open unemployment relative to

\footnotetext{
${ }^{7}$ Most program participants are classified as being outside the labor force but we follow the common practice of measuring ALMP relative to the labor force (as measured by the labor force surveys).

${ }^{8}$ Edin and Holmlund (1991) estimated that an increase in the number of unemployed by 10000 was associated with an increase in relief jobs by 5000 .
} 
what would have been achieved without the policies. Whether or not the policies have contributed to higher employment is less clear.

\section{Why Did Unemployment Rise?}

What caused the dramatic increase in unemployment in the early 1990s? The Swedish experience has similarities to what happened in Finland during the same period although the Finnish slump was deeper than the Swedish one. For both countries one could argue, along the lines of Honkapohja and Koskela (1999), that the slump was mainly driven by a combination of bad policies and bad luck. Finland had clearly more bad luck than Sweden since it lost an important part of its export market through the collapse of the Soviet Union.

The exposition that follows provides a partly chronological account of the events that led to skyrocketing unemployment. We begin by discussing the shocks that hit the economy, some of them largely self-inflicted and others more exogenous to domestic policies. Some of the shocks were mainly affecting fluctuations in unemployment around the equilibrium rate whereas other shocks may also have influenced equilibrium unemployment. ${ }^{9}$

\subsection{The Shocks that Hit}

\section{Stabilization Policy in Turmoil ${ }^{10}$}

For most of the $20^{\text {th }}$ century, Sweden pursued a fixed exchange rate policy. After the breakdown of the Bretton Woods system in 1973, the Swedish krona was first pegged to the D-mark (via the "currency snake") and from 1977 to 1991 to a trade-weighted basket of foreign currencies. A crucial requirement for the feasibility of the fixed-exchange regime was, of course, that domestic inflation was kept in line with inflation abroad. This turned out to become increasingly difficult and a series of devaluations took place in the late 1970s and the early 1980s. These devaluations resulted in substantial (albeit temporary) improvements in competitiveness that counteracted the adverse employment effects of unsustainable inflation. The large devaluations in the early 1980s paved the way for an employment expansion that lasted throughout the decade, reinforced by an international upswing as well as expansionary domestic policies. However, the expansionary domestic policies during the 1980s carried the seeds that ultimately led to a complete regime shift in stabilization policy in the early 1990s.

\footnotetext{
${ }^{9}$ Johansson et al (1999) include a detailed discussion of the nature of Swedish unemployment in the 1990s.

${ }^{10}$ The section draws on a variety of sources, including material from Konjunkturinstitutet (the National Institute of Economic Research) and OECD Economic Surveys.
} 
The credit market was one important source of domestic demand expansion. By the end of 1985, Swedish financial markets had been largely deregulated. Restrictions on household loans in commercial banks and credit institutions had been lifted, which set in motion a rapid increase in bank loans to the household sector. This change took place during a period when marginal tax rates were generally high and when mortgage payments were deductible in income taxation. The interaction of financial deregulation, progressive taxes and generous rules for deducting interest payments created the preconditions for a strong credit expansion. The total credit volume increased at an annual rate of almost 20 percent during 1985-1990. The consumption boom that followed involved a fall in the household saving rate to minus 5 percent of disposable income in 1988 and a gradual build-up of household debt.

The surge in aggregate demand contributed to a fall in unemployment along with a gradual increase in inflation. By the end of the 1980s, unemployment was approaching 1 percent of the labor force. Monetary policy was tied to defending the fixed exchange rate and fiscal policy was too lax to prevent the rise in inflationary pressure.

During the late 1980s, a government committee developed a far-reaching proposal for reform of the Swedish tax system. Key elements were lower marginal tax rates on labor earnings and the introduction of a dual system of income taxation with a 30 percent tax rate on income from capital. Mortgage payments could then be deducted at 30 percent. These reforms were put into practice in 1990 and 1991 and caused a marked increase in after-tax real interest rates. The demand for owner-occupied housing fell predictably; between 1990 and 1993, the fall in real prices amounted to 30 percent. It has been estimated that approximately half of the fall in real prices can be explained by the tax reform (Agell et al, 1995). On top of this, the household saving rate rose from minus 5 percent in 1988 to plus 7 percent in 1992. The rise in saving reflected households' attempts to bring down a debt-to-income ratio that had shown a marked increase over the 1980 s, especially during the second half of the decade.

In this environment, Swedish stabilization policy took close to a U-turn. The prime objective for decades had been full employment, although the desirability of low inflation was recognized in words. In practice, this has led governments to undertake several devaluations in the late 1970s and the early 1980s so as to restore competitiveness that had been eroded by high inflation and fixed exchange rates. In the early 1990s, the government declared that low 
inflation was the prime objective of stabilization policy. A unilateral affiliation of the krona to the ECU was declared in May 1991. The stated intention was to rule out future devaluations as escape routes from unsustainable inflation and loss of competitiveness.

In addition to self-inflicted wounds, Swedish policy making was also hit by bad luck in the early 1990s. An international recession struck during the first years of the decade. Industrial production declined between 1990 and 1993 by 4-5 percent in the EU area and by over 6 percent in Germany. The general weakening of major Swedish export markets added to the falling demand for Swedish exports and reinforced the sharp decline in GDP.

During the Fall of 1992, the krona was put under a number of speculative attacks and it became increasingly doubtful whether the fixed exchange rate was sustainable. In November 1992, the fixed exchange regime had to be abandoned and the krona was floating. A new monetary regime was established, including an inflationary target (from early 1993) and a more independent central bank (from the late 1990s).

The chronological tale told so far emphasizes two main policy failures. First, it is clear that fiscal policy was too lax in the second half of the 1980s. Unemployment reached levels clearly below available estimates of the NAIRU. ${ }^{11}$ The fixed exchange rate target had tied the hands of monetary policy and only fiscal policy tools were available to combat rising inflationary pressure. Second, it is also clear that the timing of financial deregulation and tax reform was less than optimal. Under more ideal circumstances, the tax reform should have preceded financial liberalization, rather than the other way around. Had the financial liberalization taken place in an environment with less favorable conditions for household loans, the effects on credit demand and private consumption would have been smaller.

These claims appear fairly uncontroversial, although the fine details of the impact of financial deregulation and tax reform are debatable. ${ }^{12}$ More controversial is an assessment of the policy stance vis-à-vis the emerging slump in the early 1990s. A less stubborn defense of the krona had surely cushioned the downturn and led to a less dramatic rise in unemployment. However,

\footnotetext{
${ }^{11}$ Estimates in Holmlund (1993a) indicated a trend increase in the Swedish NAIRU since the mid-1960s. According to these estimates, NAIRU was close to 3 percent around 1990, about twice as large as actual unemployment during 1989-90.

${ }^{12}$ One influential view was that the existing regulations had been undone by the "grey" credit market and that a formal deregulation would have little effect on credit volumes. Cf. the exchange between Wohlin (1998) and Englund (1998).
} 
if one takes the view that inflation carries substantial costs, its extinction is presumably worth substantial costs as well. To take a stand on this issue, one has to make an assessment of the social costs (and benefits) of inflation and unemployment.

\section{Climbing Real Interest Rates}

The rise in real after-tax interest rates in the early 1990s had essentially three sources, namely the international rise in interest rates, the tax reform that raised after-tax rates, and the steep fall in inflation. These developments triggered a decline in aggregate demand in general and housing demand in particular. However, higher real interest rates can also have "supply side" effects via firms' behavior. In particular, changes in real interest rates can influence equilibrium unemployment through the effects on the demand for labor. In the matching model of Pissarides (2000), for example, a higher real interest rate effectively works as a tax on new hires; hiring a worker carries an up-front recruitment cost and a higher rate of interest makes the "investment" in a new worker less profitable.

Swedish real interest rates exhibited a marked increase over the period 1989-92. According to one measure, the rates went up from 4 percent to double-digit figures. ${ }^{13}$ However, interest rates fell sharply when the fixed exchange rate regime was abandoned in November 1992. The empirical evidence on the relationships between real interest rates and unemployment is not conclusive and it is difficult to assess quantitatively how the interest rate shocks affected employment. It is safe to argue, however, that the interest rate hikes reinforced other adverse shocks that hit the Swedish economy in the early 1990s, thereby aggravating the fall in employment. Some back-of-the-envelopes calculations in Edin and Holmund (1997) suggest that the rise in the real interest rate that took place could translate into a non-negligible increase in equilibrium unemployment.

\section{Falling Public Sector Employment}

Public sector employment in Sweden expanded rapidly from the early 1960s to the mid 1980s. The major increases took place during the 1970s where public employment increased by 4-5 percent per year, most of it in local governments. By the end of the 1980s, the number of public-sector employees accounted for 40 percent of the total wage and salary employment. In the early 1990s, however, the rise in public employment came to a sharp halt. In fact, between

\footnotetext{
${ }^{13}$ The figures are based on nominal interest rates for 3 months treasury bills and the producer price index.
} 
1990 and 1994, the number of public sector employees declined by 15 percent, or by around 250000 persons. This was equivalent to a decline in employment relative to population of 5 percentage points. Figure 3.1 shows how public employment has evolved since the late 1970s.

It is likely that this apparently dramatic fall in public sector employment overstates the amount of job destruction that actually took place. The 1990s witnessed much organizational restructuring and privatization and some of the decline in public sector employment reflects these organizational changes rather than job destruction. However, the organizational changes that took place may also have increased competitive pressure and involved some initial shakeout of labor.

Figure 3.1 Public sector employment as percent of population aged 16-64, 1977-2002.

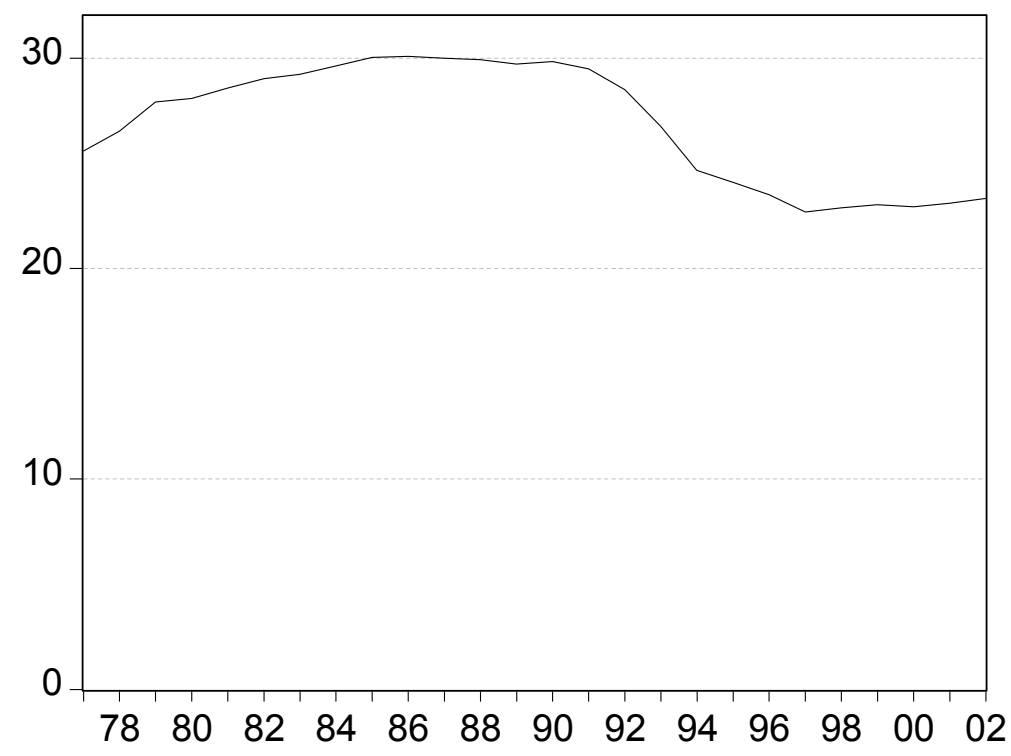

Source: Labor force surveys, Statistics Sweden.

To assess the impact of public sector employment on unemployment one has to distinguish between the short run and the long run. The short run (impact) effect on actual unemployment is likely to differ from the long run effect on equilibrium unemployment. Moreover, changes in public employment may in itself be endogenous to movements in unemployment. Indeed, public employment displayed a countercyclical pattern in Sweden during the 1960s and the 1970s (and to some degree also during the 1980s); see Edin and Holmlund (1994). This being said, one can still with reasonable confidence sign the impact effect of cutbacks of public 
employment. The fall in public employment in the early 1990s almost certainly contributed to the rise in unemployment.

An assessment of the long-run effect of public sector employment on unemployment is more difficult. Clearly, a rise in public employment financed by taxes is likely to induce some crowding out of private sector employment. Theoretical models in this area include papers by Holmlund (1993, 1997) and Algan et al (2002). A plausible benchmark case is where the long run effect on unemployment is zero. In a standard model of decentralized bargaining between unions and employers, this long run neutrality result holds if the bargaining power of unions does not differ between private and public sectors.

Empirical studies in this area face difficult problems of identifying the causal effects of public employment on unemployment. The studies are few and the results are mixed. For example, Edin and Holmlund (1997) could not find any long run effect although they did find a negative and significant short run effect. Algan et al (2002) report results that are somewhat sensitive to the exact specification; their preferred estimates suggest that an expansion of public employment would actually increase unemployment in the long run.

Summing up, the early 1990s saw a number of adverse shocks to employment. In addition to the shocks affecting private-sector employment, there was also a marked decline in public sector labor demand. Although the long run effect of public sector contraction may well be negligible, the short run impact almost certainly reinforced the steep rise in unemployment.

\section{$\underline{3.2 \text { Work Hours, Absenteeism and Cyclical Unemployment }}$}

The extent to which adverse shocks to labor demand have immediate effects on employment and unemployment depends on the costs of adjusting work hours as well as the number of workers. Flexible work hours can to a degree function as an adjustment margin that reduces fluctuations in employment. In Sweden, however, average hours per worker are countercyclical.

Why do actual work hours exhibit this behavior? Rules pertaining to unemployment insurance (UI) and temporary layoffs are part of the explanation. Consider first the role of UI. A decline in labor demand that is met by layoffs - full time unemployment for those laid off - is associated with UI payments to the affected workers. On the other hand, if the decline is met 
by work sharing - part-time unemployment for all workers - there will be no benefits available to compensate for the income loss. The UI rules thus effectively discourage work sharing as a device to cope with adverse shocks.

The rules pertaining to temporary layoffs (permitteringar) have similar effects. A worker temporarily laid off, while retaining his employment contract with the firm, is classified as absent from work in the labor force surveys and is eligible for temporary layoff pay. This layoff pay equals the worker's regular earnings and is (mainly) provided by the firm responsible for the layoff. In other words, stiff experience rating effectively penalizes temporary layoffs.

Another factor of importance is absence behavior over the business cycle. A notable feature of Swedish absenteeism is its marked pro-cyclicality. In 1990, the fraction of employed absent from work during a whole week was on average close to 18 percent; in the mid-1990s, absenteeism had fallen to 14 percent; see Figure 3.2. An important element of this pattern is pro-cyclical sick absenteeism. It is debatable to which extent pro-cyclical sick absence reflects fluctuations in the composition of the workforce as opposed to true behavioral effects, i.e., the disciplining effect of high unemployment. The presumption is that both mechanisms are at work.

Pro-cyclical absenteeism reinforces the negative employment effects of adverse shocks to labor demand. Symmetrically, it reinforces the positive employment effects of favorable shocks. When absenteeism falls, there is less need to hire new workers to replace those absent from work. Analogously, there is more need to hire replacement workers when absenteeism increases. The magnitude of the potential employment effect is non-trivial. As shown in Figure 3.3, there is a marked rise in hours per employed worker during the early 1990s. The rise of about 4 percent can be taken as a rough indication of the magnitude of the potential employment effect. If hours and workers were perfect substitutes in production, and absent fixed costs per worker, a rise in work hours by 4 percent would translate into a decline in employment by approximately 4 percent. Of course, the actual effect is lower because of imperfect substitutability and fixed costs. However, the magnitude of the potential effect is substantial. The introduction of liberal rules for temporary work agencies (see below) may also have reduced the costs of using replacement workers, thus effectively increasing the substitutability between workers and work hours. 
Figure 3.2 Absence rates among employed workers 1987-2002, percent. Seasonally adjusted quarterly data.

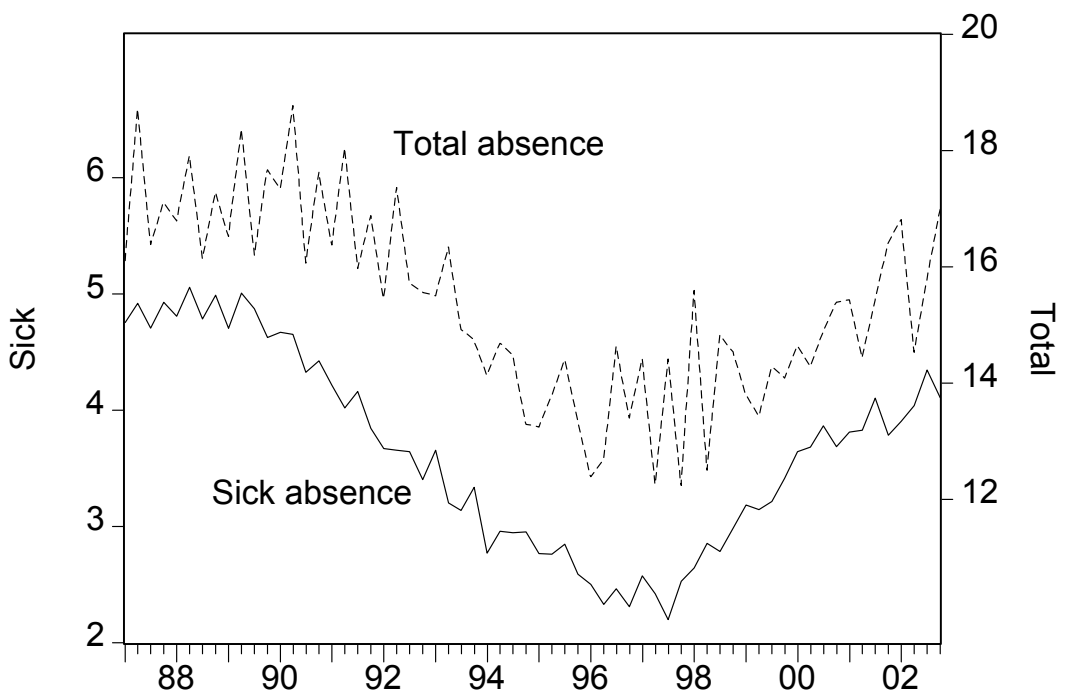

Note: The measures refer to absence during a whole week, all employed workers. Source: Labor force surveys, Statistics Sweden.

Figure 3.3 Average hours of work per week 1987-2002. Seasonally adjusted quarterly data.

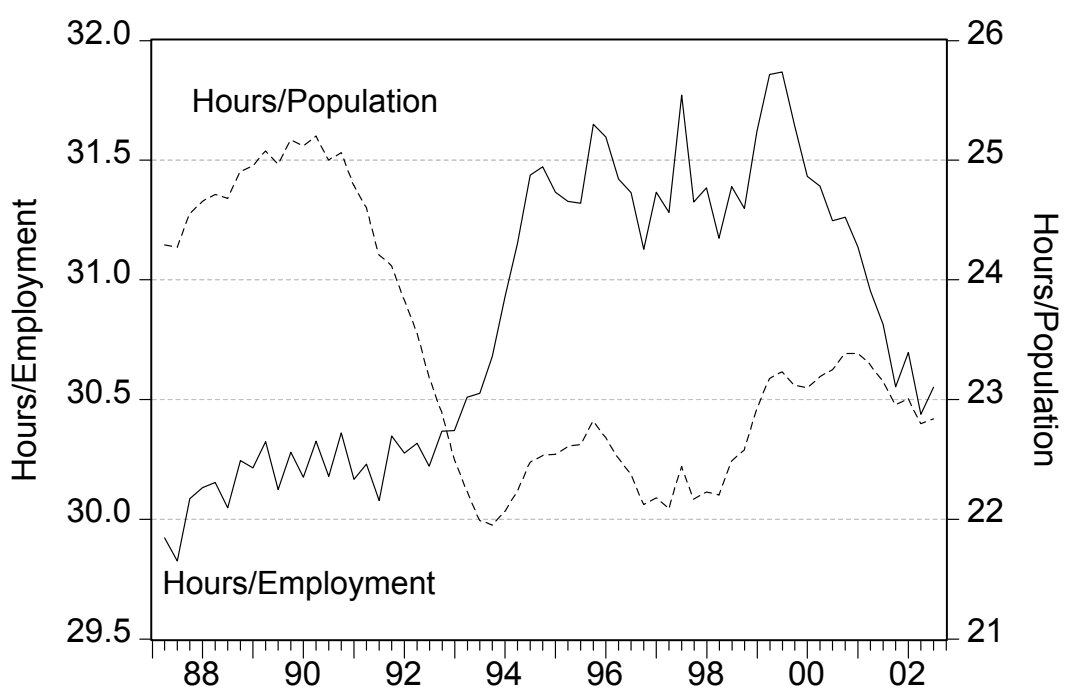

Note: The seasonally adjusted data have been smoothed by a three-quarter moving average. Source: Labor force surveys, Statistics Sweden. 
To conclude, it is clear that movements of work hours do not tend to offset the employment effects of adverse shocks to labor demand. By contrast, countercyclical work hours tend to reinforce the adverse effects on employment. In all likelihood, the decline in absenteeism, and associated rise in work hours, contributed to the rise in unemployment in the early 1990s. ${ }^{14}$

\subsection{Other Suspects}

We have emphasized macroeconomic shocks as main explanations of why unemployment rose so sharply in the 1990s. For completeness, a few other candidate explanations need to be addressed. They belong to the group of usual suspects when one considers determinants of equilibrium unemployment. However, it is difficult to convincingly prove the guilt of any of these suspects.

\section{Unions and Wage Bargaining}

A high degree of unionization is a fundamental ingredient of what has been referred to as the Swedish Model. Labor legislation is based on the presumption that the overwhelming majority of workers belong to a union. Indeed, union density has hovered above and around 80 percent of the number of employees over the past couple of decades. The coverage of collective agreements is even higher. The shocks that kicked Sweden into a major slump had nothing to do with a sudden surge in union density. In fact, union density declined slightly from 82 to 80 percent - between 1987 and 1990 (Kjellberg, 2001).

An arguably more promising explanation focuses on changes in wage bargaining systems. The heydays of centralized wage bargaining in Sweden were the period 1956-1983, which involved nationwide negotiations between the peak employee and employer organizations. This system came under increasing stress during the late 1970s when some employer organizations argued that the central frame agreements left too little room for flexibility at the local and industry level. A significant step towards more decentralized wage bargaining came in 1983, when the metalworkers' union and their employer counterpart sidestepped the national negotiations and opted for an industry agreement. Wage negotiations after 1983 have mainly taken place at the industry level, albeit with some exceptions.

\footnotetext{
${ }^{14}$ The argument presupposes that these changes in work hours had negligible effects on hourly wages. As is well known, some types of working time changes can influence wage determination (Hunt, 1999; Nordström Skans, 2002). In the short run, however, one can reasonably take hourly wages as given.
} 
It is possible that the breakdown of centralized bargaining contributed to some increase in wage pressure and made it more difficult to curtail inflation in the late 1980s. It seems unlikely, however, that the impact was strong. In fact, when the slump was underway, wage bargaining reverted temporarily to a highly centralized arrangement. The government initiated a nationwide incomes policy for 1991-93 so as to bring inflation under control. This policy involved coordination to an unusual degree, incorporating virtually all employer organizations and most of the unions.

Finally, it is noteworthy that recent econometric evidence reveals a remarkable stability of Swedish wage setting relationships. The available studies find no evidence of structural breaks in the early 1990s (Forslund and Kolm, 2000; Holden and Nymoen, 2002; Nymoen and Rødseth, 2003).

\section{Unemployment Insurance}

Sweden has a generous UI system where pre-tax replacement rates for eligible workers have reached 90 percent during some years. Although the system is voluntary, it is heavily subsidized and its coverage has shown a trend increase. On average some 65 percent of the stock of unemployed registered at the public employment offices received UI during 1990-1995 (see SOU 1996:51, p. 51). The fraction of new spells of unemployment covered by UI was even lower. Carling et al (1996) report that less than 50 percent of the inflow of new unemployed received regular UI compensation in the early 1990s.

Unemployment benefits cover a fraction of previous earnings up to a ceiling. The average replacement rate for a population of workers is thus based on the statutory replacement rate (up to the benefit ceiling) as well as the ceiling. The development of average replacement rates has shown a trend increase from the early 1960s to the 1980s (Björklund and Holmlund, 1991; Forslund and Kolm, 2000). In the late 1980s, average replacement rates hovered around 85-90 percent. Although benefit payments were formally limited to 60 weeks for most workers, the practice of allowing qualification through labor market programs effectively increased maximum duration substantially.

The trend increase in the generosity of UI is a prime candidate explanation of the trend increase in the duration of unemployment between 1960s and the 1980s. However, it is difficult to identify specific sharp changes of UI around 1990 that could explain the rise in 
unemployment in the early 1990s. It might perhaps be argued that the existence of a generous benefit system reinforced the rise in unemployment, even if the rise was ultimately caused by adverse macroeconomic shocks; this is the interaction argument discussed by Blanchard and Wolfers (2000). There are two problems with this argument, however. First, generous benefits strengthen the automatic stabilizers in the economy, thus reducing the adverse employment effects of recessionary shocks. Second, absent changes in institutions it is virtually impossible to identify empirically these interaction effects from data pertaining to a single country.

\section{Taxes}

The period from the early 1960s to the late 1980s exhibited an almost monotonic rise in the total tax pressure. The total tax wedge, including direct and indirect taxes on workers and payroll taxes on employers, increased by over 50 percent over this period. ${ }^{15}$ The fact that unemployment remained low strongly suggests that most of these tax increases were borne by labor in the form of slower growth of real take-home pay. A marked trend reversal took place in the early 1990s and involved base broadening and lower marginal tax rates. It was certainly not a sharp rise in the tax wedge that threw Sweden into mass unemployment in the early 1990s.

The fact that the tax reform substantially reduced tax progressivity raises the possibility that this reform added to wage pressure by reducing the costs of wage increases. Some theory as well as some empirical work suggests that progressive taxes may bring about wage moderation when there is bargaining over wages. Holmlund and Kolm (1995) use their estimated wage pressure effects in some back-of-the envelopes calculations and find that the decline in tax progressivity between 1989 and 1992 may have raised equilibrium unemployment by around one percentage point. The empirical evidence on wage behavior and tax progressivity is somewhat mixed, however. For example, Forslund and Kolm (2000) cannot confirm that lower progressivity increases wage pressure.

\section{Matching}

Was the rise in unemployment driven by an increase in mismatch between job searchers and vacancies, by a general deterioration in matching efficiency, or by a fall in search effort? If

\footnotetext{
${ }^{15}$ The measure of the total tax wedge is $\theta=(1+s)(1+v a t) /(1-t)$, where $s$ is the payroll tax rate (levied on firms), vat is the value added tax and $t$ is the income tax paid by workers. See Forslund and Kolm (2000) for more information about the evolution of tax wedge.
} 
any of these changes were important, we should observe outward shifts of the Beveridge curve. Figure 3.4 shows Beveridge scatter-plots for unemployment and vacancy rates. ${ }^{16}$ The rise in unemployment seems to be best characterized as a movement along a convex Beveridge curve rather than as a shift of the curve.

Recall that the increasing unemployment in the early 1990s was associated with a sharp increase in the inflow to unemployment, a fact that by itself produces an outward shift of the Beveridge curve. To gauge the importance of the inflow effect we have estimated a simple " $u, v$-model" that controls for the inflow rate. ${ }^{17}$ Figure 3.5 illustrates an "inflow constant" Beveridge curve that is generated by a dynamic simulation from 1985 with the inflow rate fixed at its 1985 value. The outward loop is much less marked in this figure than in Figure 3.4, confirming the importance of the inflow effect.

Figure 3.4 Beveridge curve for Sweden 1983-2001 (percent of labor force).

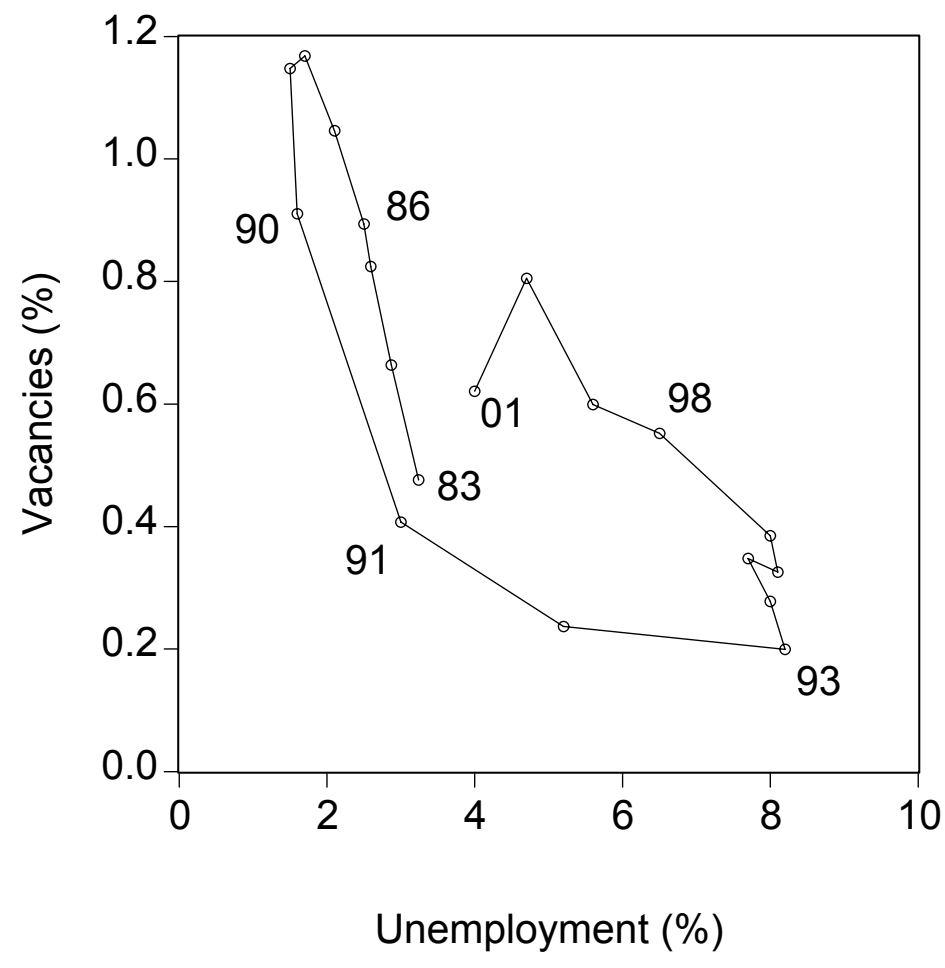

\footnotetext{
${ }^{16}$ The vacancy data refer to the number of unfilled vacancies at the public employment service.

${ }^{17}$ The estimated model is: $\ln u=0.154-0.39 \ln v_{-1}-0.49 \ln \left(v / v_{-1}\right)+0.53 \ln u_{-1}+0.34 \ln i u$, where $u$ is the official unemployment rate $(\%), v$ the number of unfilled vacancies relative to the labor force $(\%$,$) , and i u$ the weekly unemployment inflow relative to the labor force (\%). Estimation period: 1977-2001, annual data. Adjusted Rsquared is 0.992 , DW 1.780, SE 0.054 and AR(1) 0.36 .
} 
Table 3.5 Beveridge curve with constant inflow (percent of labor force).

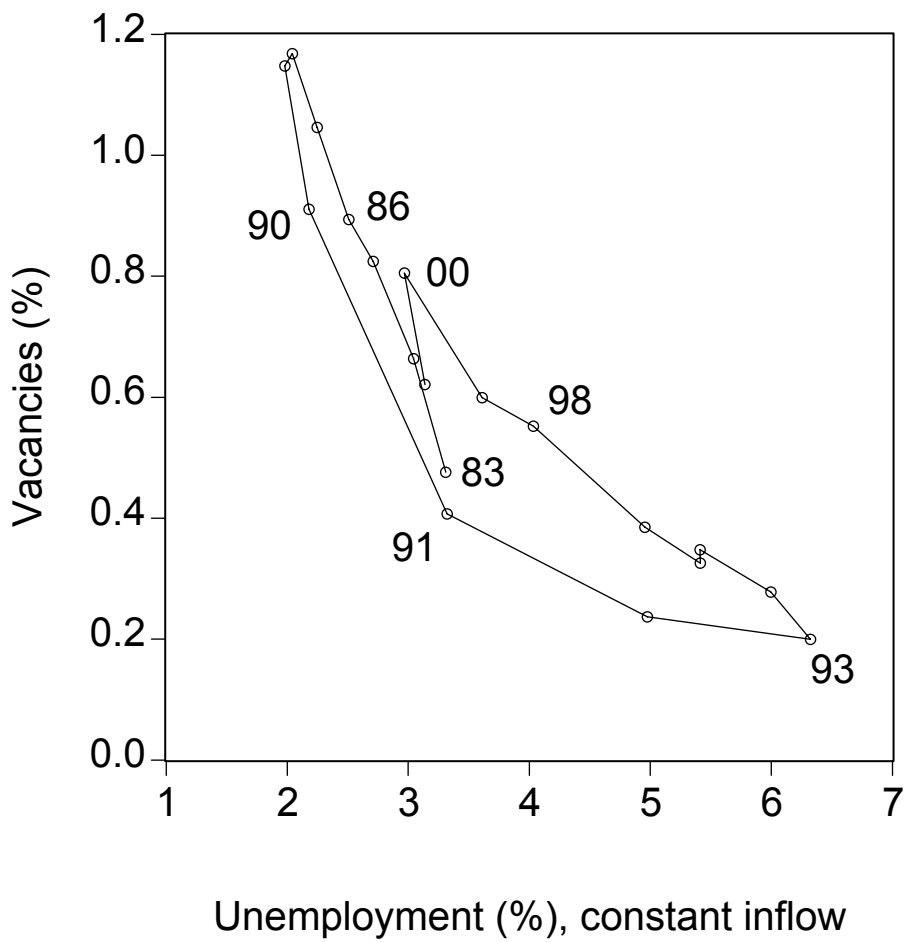

Summing up, the rise in unemployment in the early 1990s cannot easily be attributed to deteriorating matching efficiency or an increase in mismatch. Nor can it plausibly be attributed to a sudden fall in search effort since it is hard to identify sharp adverse changes in the incentive structure. In fact, one could argue that the major tax reform of 1990-91 should have encouraged labor market participation and perhaps job search activity.

\section{Demographic Changes}

Did changes in the age composition of the labor force contribute to the rise in unemployment? Unemployment and nonemployment vary substantially across age groups, in Sweden as elsewhere. If a group with a high "natural" unemployment rate becomes relatively larger, there is a presumption that overall unemployment will increase. A simple shift share analysis can shed light on this issue. An "age-constant" nonemployment rate $\left(n^{*}\right)$ is obtained by using group-specific nonemployment rates and time-invariant population shares:

$$
n_{t}^{*}=\sum w_{i} n_{i t}
$$


The population share of group $i$ at some base year is denoted $w_{i}$ and $n_{i t}$ is the nonemployment rate for group $i$ during year $t$. A positive difference between the actual and the age-constant nonemployment rate implies that the age structure has contributed to a rise in nonemployment. Figure 3.6 shows the results when using the population shares for seven age groups with 1990 as base. The basic message is that the age structure tended to increase nonemployment during the 1980 s whereas it tended to reduce nonemployment during the second half of the 1990s. The maximum effects in both directions amount to one percentage point. The age structure effect is negligible during the early 1990s. During the 1990s, the relative size of youth cohorts (16-19 and 20-24) declined, a fact that accounts for the negative difference between actual and age-constant nonemployment over the second half of the decade.

Of course, these exercises are mechanical and ignore various indirect effects, including effects on matching efficiency (cf. Shimer, 2001, and Nordström Skans, 2002). It seems safe to conclude, however, that the causes of the steep rise in nonemployment in the early 1990s had little to do with demographic changes.

Figure 3.6 Actual and "age-constant" nonemployment rates 1976-2001.

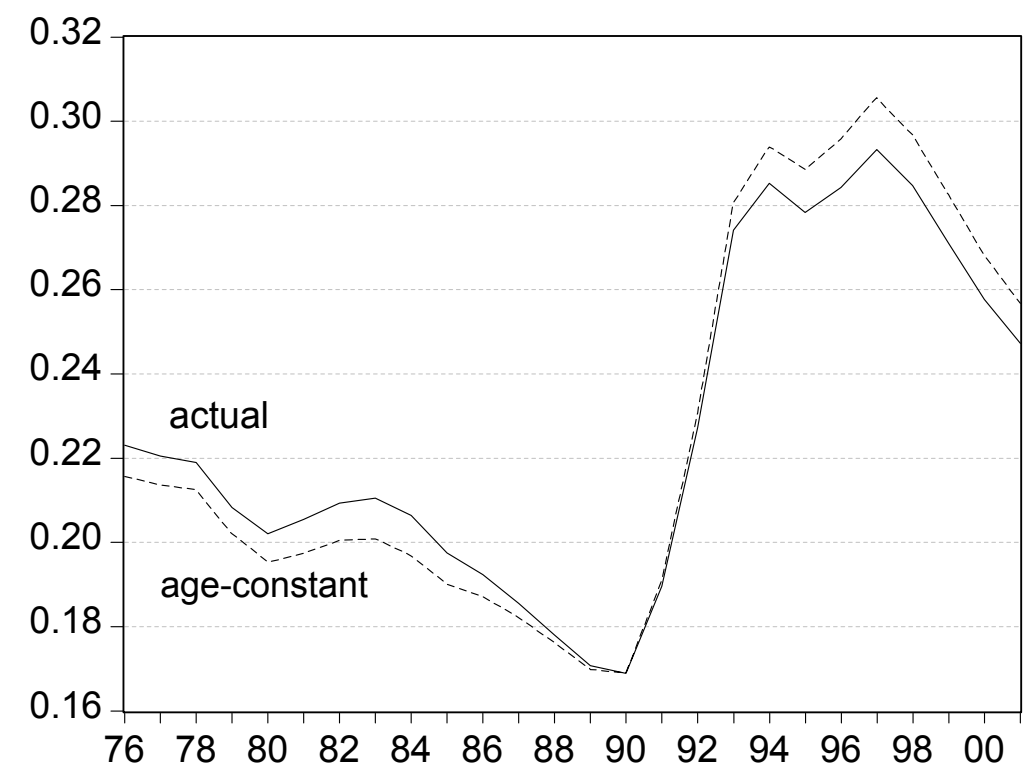

\section{$\underline{3.4 \text { A Rise in Equilibrium Unemployment? }}$}

Several studies have attempted to estimate the equilibrium unemployment rate in Sweden. The methods vary and so do the results, although differences in methods do not seem to 
explain differences in results. Some early studies focused on changes in inflation and attempted to determine the unemployment rate consistent with stable inflation. A more ambitious structural approach involves estimation of price- and wage-setting schedules. More recent work has made use of structural time-series models. Almost all attempts to estimate the NAIRU arrive at series that can be described as smoothed versions of the actual unemployment rate.

The estimates in Holmlund (1993) indicated a trend rise in NAIRU since the mid-1960s and a NAIRU close to 3 percent around 1990. Forslund (1995) estimated wage and price setting schedules and solved for the equilibrium unemployment rate; this turned out to be around 4-6 percent in the early 1990s. Elmeskov et al (1998) reported estimates according to which NAIRU had risen by 4 percentage points between the late 1980s and the mid-1990s. Apel and Jansson (1999) presented system estimates of potential output and the NAIRU using unobserved components methods. The results differed depending on the exact specifications. Some specifications indicated a marked rise in the NAIRU over the 1990s, whereas others indicated only marginal changes. Recent estimates reported by Konjunkturinstitutet (2002) suggest that the NAIRU was around 2 percent during the 1980s and hit 5 percent in the mid1990s.

What can be said, then, about equilibrium unemployment in the 1990s? Climbing real interest rates probably added to some increase in the NAIRU in the early 1990s but otherwise it is difficult to identify sharp changes in the usual structural suspects - benefits, labor market institutions, taxes etc - that could explain the huge rise in unemployment. The steep rise in unemployment is best understood as being mainly the result of a series of adverse macroeconomic shocks. ${ }^{18}$ It should be recognized, however, that the shocks hit when unemployment in all likelihood was well below the NAIRU; at least part of the rise thus reflected an adjustment towards a more sustainable level of unemployment.

\footnotetext{
${ }^{18}$ A caveat here is that a cyclical rise in unemployment may lead to a rise in the NAIRU if there are strong hysteresis mechanisms. Assarsson and Jansson (1998) and Lindblad (1997) find some evidence that support this possibility in the Swedish case. However, the strong labor market rebound of the late 1990s casts doubt on the importance of this mechanism.
} 


\section{Why Did Unemployment Fall?}

In the mid-1990s, unemployment hovered around 8 percent and employment was stagnant or even falling. The central bank struggled to establish credibility for the new low inflation regime whereas the government's overriding concern was to bring about fiscal consolidation. These priorities led to generally restrictive stances of both monetary and fiscal policies and contributed to the weak employment performance in the mid-1990s. However, the policies achieved their goals in terms of credible low inflation and fiscal consolidation. When the fiscal goals were met by the late 1990s, tax and expenditure policies became more expansionary and monetary policy was eased to support the expansion.

The 1990s also saw several structural changes that may have reduced the equilibrium unemployment rate. Some of these changes were the results of policy decisions, such as cuts in unemployment benefits and regulatory reforms aiming at increased competition in product markets. Other changes, such as innovations in wage bargaining arrangements, were not directly caused by government policies although they may have been influenced by changes in the macroeconomic environment. The rise in employment was probably also facilitated by the demographic development.

\section{$\underline{4.1 \text { Macroeconomic Policies }}$}

\section{Monetary Policy}

When the krona was left to float in November 1992, it depreciated immediately and by the end of 1992 it had fallen by 15 percent against the ECU. Competitiveness was restored to a level comparable to the situation after the devaluation in 1982. The improved competitiveness as well as stronger market growth brought about a rise in exports. Between 1993 and 1995, manufacturing output increased by over 20 percent and manufacturing employment by around 15 percent. Despite this marked rebound, the overall effect on employment was initially negligible because of negative contributions to growth from private and public consumption.

In early 1993, the central bank announced a strategy of inflation targeting. The goal of monetary policy should be to stabilize annual consumer price inflation at 2 percent, with a margin of tolerance of \pm 1 percentage point. A new amendment to the central bank legislation, in force from 1999, gave the central bank greater independence from direct political influence. A new executive board consisting of six full-time members was made responsible for monetary and exchange rate policies. 
By and large, the new framework for monetary policy has been successful in achieving its main goal. Inflation has stayed within the tolerable band for most of the time and a credible low inflation regime has been established. The average annual rate of consumer price inflation has been 1.6 percent over the period 1993-2002, thus undershooting the inflation target. But the low inflation regime did not materialize without costs. Available survey-based estimates of inflation expectations from around 1995 indicated that the low inflation target was far from universally credible. According to some measures, expectations of medium-term inflation hovered around 4 percent. These stubborn inflation expectations triggered a series of central bank interventions to establish its non-inflationary credentials. The repo rate (the main signaling rate) was raised in steps between 1994 and 1995, reaching close to 9 percent in the second half of 1995 . These policies appeared to be effective as inflation as well as inflation expectations fell over the next couple of years and paved the way for a series of repo rate reductions during 1996.

Has the successful conquest of inflation been good or bad for employment? The generally restrictive monetary policy of the mid-1990s probably delayed the economic upswing although it may have been necessary in order to secure credibility for the low inflation target. There is also the more general issue of whether the new monetary policy framework is employment-friendly or not. There are pros and cons in this matter. On the pros side, it can be argued that a more independent central bank strengthens incentives for wage moderation. On the cons side, an ambitious price stabilization target is arguably in conflict with ambitious employment goals in the presence of nominal rigidities.

The possibility that wage moderation is encouraged by central bank independence hinges on a strategic interaction between wage setters and the central bank and is relevant only if wage setting takes place in a coordinated fashion. With coordinated negotiations, the parties in the bargain will recognize - and hence internalize - that monetary policy responds to wage decisions. A more independent ("conservative") central bank works as a deterrent to wage increases (Rantala, 2001). However, if wage negotiations are decentralized and uncoordinated, decisions on wages will not internalize monetary policy reactions. As we shall se, Swedish wage setting took a turn towards enhanced coordination in the second half of the 1990s. The interaction of a more independent central bank and more coordinated wage bargaining arrangements has arguably been good for employment. 
The cons side in this matter revolves around the idea that inflation may grease the wheels of the labor market. As emphasized by Akerlof et al $(1996,2000)$ and others, it is plausible that an ambitious inflation target in the presence of nominal rigidities can be bad for employment. Indeed, the choice of a positive inflation target reflects in part the presumption that nominal wages are rigid. Relative wage changes in a non-inflationary environment may require nominal wage reductions, something that is difficult to achieve. The presence of nominal wage rigidities is confirmed in several empirical studies, including Fehr and Goette (2000) for Switzerland and Nickell and Quintini (2001) for the UK.

Some recent studies have tried to pin down the role of nominal rigidities for the long run Phillips curve. These contributions include Akerlof $(1996,2000)$ for the U.S. and Lundborg and Sacklén (2001) for Sweden. The results suggest that the long run Phillips curve is negatively sloped at low inflation rates. Taking the estimates in Lundborg and Sacklén at face values, the inflation rate that minimizes Swedish unemployment would be around 4 percent. ${ }^{19}$

The bottom line here is that we can be reasonably sure about the existence of nominal rigidities in actual labor markets. It is much more difficult to ascertain how these rigidities affect real rigidities and unemployment-inflation tradeoffs. It is plausible that a less ambitious Swedish inflation target would have boosted faster employment growth over the 1990s but it takes an act of faith to state the magnitude of this effect.

\section{Fiscal Policy}

During 1993, the consolidated public sector's budget deficit stood at 12 percent of GDP. The government's debt-to-GDP ratio amounted to 76 percent by the end of the year. The need to bring government finances under control became a top priority for the new (social democratic) government in 1994. The following years involved a major effort to stabilize government debt and to reduce the budget deficit. The program entailed expenditure cuts, especially concerning transfers, as well as tax increases. The policies were resoundingly successful in terms of the stated objectives: by the end of the decade, the government's budget deficit was eliminated and the debt-to-GDP ratio had declined to 60 percent.

\footnotetext{
${ }^{19}$ The analysis follows Akerlof et al (2000) and builds on the idea that many agents ignore inflation as long as it is low. High inflation is costly to ignore, however, and the standard NAIRU model applies in this region. The long-run Phillips curve is negatively sloped for low inflation, positively sloped for intermediate inflation and vertical for high inflation.
} 
The generally contractive fiscal policy is one reason why unemployment remained stubbornly high in the mid-1990s. However, the fiscal consolidation added credibility to the antiinflationary stance of macroeconomic policy. Fiscal policies were eased to support growth of private and public consumption as the budgetary goals were met and absent any visible threat to the low inflation target.

One ingredient of the fiscal consolidation was the introduction in 1996 of a new system for decisions on government expenditure. The goal was to establish a long-term approach to expenditure decisions. The key innovation involved three-year nominal expenditure ceilings. In year 1997, say, decisions should be taken on expenditure for 1998, 1999 and 2000. To some degree, this system tied the hands of fiscal policy, although some room was left for discretionary policies. This reform was followed by a decision to set a goal for the general government budget surplus of 2 percent of GDP as an average over the business cycle.

\subsection{Towards a New Regime for Collective Bargaining}

With double-digit wage inflation and an emerging cost crisis, the government initiated a "stabilization drive" in 1990 so as to achieve a deceleration of wage inflation. The drive took the form of a government-appointed commission that delivered a proposal for economy-wide wage restraint for the period 1991-1993. This involved negotiations with over 100 organizations and the proposal was finally accepted across the whole labor market. The efforts appear to have been largely successful. Wage inflation was running at 10 percent in the late 1980s and had fallen to 4 percent in 1992 and 2-3 percent in the 1993 and 1994. It is difficult to delineate the precise causes of this decline. The rapidly worsening of labor market conditions certainly promoted wage restraint but the speed at which the decline took place suggests that the stabilization drive also had some impact. The following years involved a return to largely uncoordinated industry-wide bargaining, albeit with some effort to mimic coordination via the active involvement of mediators. Wage increases in the mid-1990s were on the rise and seemed to threaten the inflationary target. However, high productivity growth and high profit margins in the business sector moderated the impact on price inflation.

In the summer of 1996, several blue-collar unions in the manufacturing sector launched an important initiative that eventually materialized as the so-called Industrial Agreement (IA) of 1997. The agreement was struck by the blue- and white-collar unions as well as employer organizations in the industrial sector and was mainly concerned with procedural "rules of the 
game". It represented an attempt to establish consensus around timetables for negotiations, the role of mediators, and rules for conflict resolution. A group of "impartial chairs" have been appointed and the agreement states rules for when and how these chairs could intervene in the negotiation process. For example, they can order a delay of industrial action for up to two weeks. The IA model also involves a group of independent economic experts that provide basic information about wage developments and general macroeconomic issues. ${ }^{20}$

The Industrial Agreement has served as a model for similar agreements in the public sector (and also in parts of the service sector). As of 2002, over 50 percent of the labor force is covered by IA-type agreements. IA also came to serve as a model for government policies concerning industrial relations. A new national mediation institute (Medlingsinstitutet) has been created (in operation from June 2000) with the power to appoint mediators even without the consent of the parties concerned.

The IA innovations that emerged in the late 1990s represent a move towards informal coordination in wage bargaining. The new rules of the game and the efforts to build consensus on wage developments consistent with low inflation and high employment may have borne some fruit in terms of wage moderation. The reforms pertaining to monetary policy discussed above may have reinforced the incentives for wage moderation. It is difficult, however, to assess quantitatively how important this effect has been.

Perhaps paradoxically, the move towards informal macro-coordination in wage bargaining has taken place simultaneously with a clear shift towards stronger local influence over the distribution of wage increases. Pay setting in the public sector is a case in point. Previous rigid wage scales have been abandoned and there is, at least in theory, substantial room for wage adjustments tailored to the needs of recruiting and retaining employees.

\subsection{Employment Regulations and Temporary Work}

\section{Fixed-Term Contracts}

The Swedish legislation on employment protection presumes that, unless otherwise stipulated, an employment contract is valid until further notice. When terminating the contract the employer must provide a valid reason and advance notice. Compared to many other OECD

\footnotetext{
${ }^{20}$ See Elvander (2002) and Ohlsson (2002) for analyses and discussions of the industrial agreement.
} 
countries, the periods of notice are lengthy but no redundancy pay is stipulated. The grounds for collective redundancies are liberal although they have to proceed in accordance with seniority. During the 1990s there have been no significant reforms of the employment protection legislation concerning the termination of open-ended contracts. There have, however, been several changes concerning the regulation of fixed-term contracts.

In January 1994 the maximum permitted duration for probationary contracts and those motivated by a temporary increase in labor demand were prolonged from 6 to 12 months. However, this was immediately repealed in January 1995 when a social democratic government had returned to power. A new law in 1997 introduced the opportunity to strike collective agreements on derogations from statutory law regarding fixed-term contracts at the local level, provided that the parties had a central agreement on other matters. Prior to 1997, these agreements could only be made at the central (usually national) level. The 1997 legislation also opened up for fixed-term contracts without specified reasons.

The sharp fall in total employment in the early 1990s was due to sharply falling "permanent" (open-ended) employment and not the result of a decline in the number of fixed-term contracts. In fact, the number of fixed-term contracts stood at approximately the same level in the first quarter of 1994 as it did four years earlier. The overall decline in total employment was marginally offset by a slight increase in self-employment.

Figure 4.1 displays the evolution of permanent and temporary employment over the period from 1987 and onwards. The strikingly different developments of permanent and temporary employment stand out. When the economy approached the cyclical peak in the late 1980s, we observe rising permanent employment along with a decline in the number of fixed-term contracts. From the early 1990s and during most of the rest of the decade there is a remarkable increase in fixed-term contracts that amounts to roughly 50 percent. Measured relative to total wage and salary employment, the number of temporary workers rose from 10 percent to 16 percent; see Figure 4.2. Notice also the declining share of temporary workers over the late 1990s with generally improving labor market conditions, a development similar to the late $1980 \mathrm{~s}$.

Why did fixed-term contracts exhibit this almost relentless growth during the 1990s? Holmlund and Storrie (2002) discuss this issue and conclude that legislative changes are 
unlikely to be important. A more promising explanation focuses on the consequences of adverse macroeconomic conditions. A recession is associated with relatively more hirings on temporary contracts, presumably reflecting stronger incentives on part of firms to offer shortterm jobs when workers are easier to find as well as an increased willingness on part of workers to accept temporary work when job offers in general are in short supply. The Swedish experience as well as the developments of temporary work in the other Nordic countries lends support to this hypothesis. The share of temporary work has been relatively stable in Norway (with stable or falling unemployment) but increased sharply in Finland over the 1990 s, i.e., a period when Finnish unemployment skyrocketed. ${ }^{21}$

The effects of a rising number of fixed-term contracts on flows into unemployment are obvious, at least in an accounting sense: the higher the share of fixed-term contracts, the larger the inflow to unemployment as these contracts entail substantially higher unemployment risks than open-ended contracts. ${ }^{22}$ As noted, there has been a marked rise in unemployment inflow over the decade. Roughly 50 percent of this rise in inflow can be accounted for by higher inflow from temporary jobs. To the extent that there has been a trend rise in temporary work that will prevail also in favorable macroeconomic conditions - which seems reasonable - it is conceivable that it has contributed to some increase in equilibrium unemployment through higher job separation rates.

Fixed-term contracts may however also have favorable effects on job finding, as firms are likely to perceive such contracts as less risky than open-ended ones. Indeed, there is some evidence that participation in temporary employment in Sweden may reduce subsequent unemployment (Korpi and Levin, 2001). The overall effect on duration from increased prevalence of temporary jobs is not easily quantified, however. As a crude check of possible effects on unemployment duration we estimated several equations explaining transition rates from unemployment to employment using aggregate data on quarterly transition rates for the period 1987-2000. In addition to a measure of labor market tightness, the fraction of temporary workers in total employment was included as independent variable. The latter

\footnotetext{
${ }^{21}$ The countercyclicality of temporary jobs is confirmed by simple regressions. If the share of fixed-term contracts is taken as dependent variable and the vacancy/unemployment ratio as the cyclical variable, the latter variable enters with a negative and statistically significant coefficient. See Holmlund and Storrie (2002) for further results and discussions.

${ }^{22}$ Over the period 1987-2000, the flow data from the labor force surveys indicate that the average risk of becoming unemployed was more than ten times higher for a temporary worker than for a worker on an openended contract.
} 
variable might serve as a proxy for the fraction of job openings that involves fixed-term contracts. However, the proxy-variable did not come out significant.

Figure 4.1 Permanent and temporary wage and salary employment 1987-2002 ('00s, seasonally adjusted quarterly data).

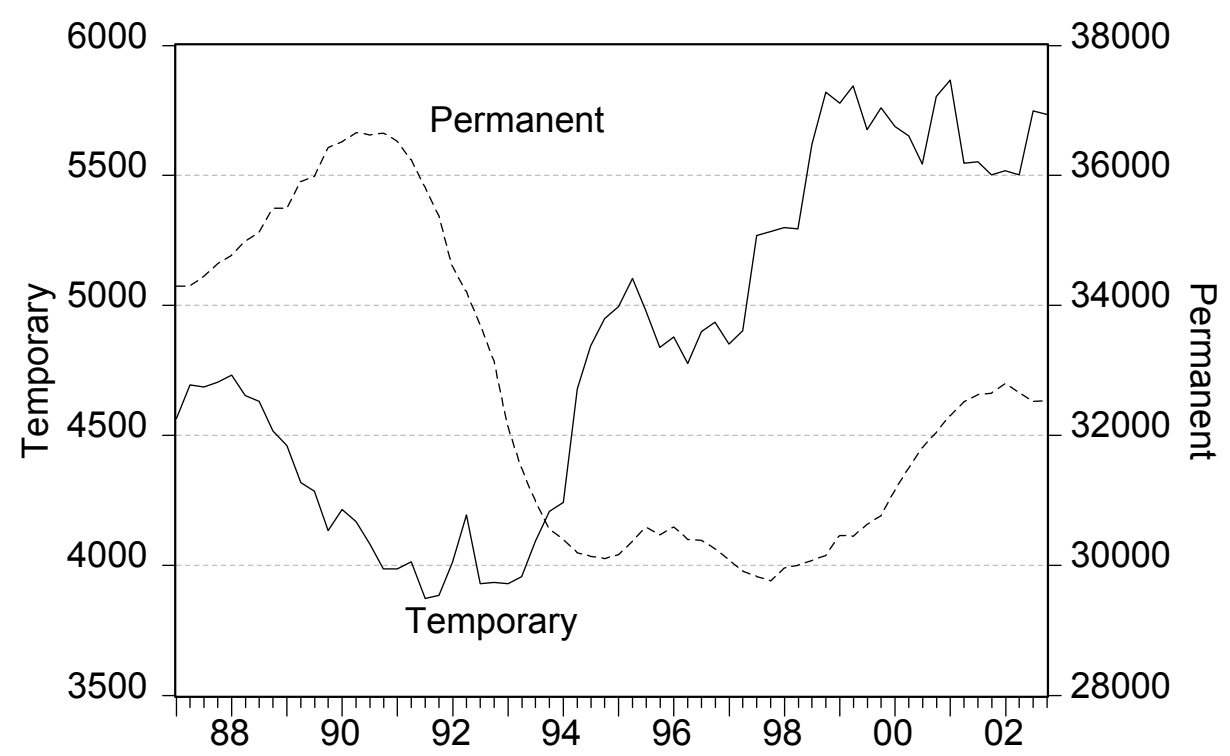

Source: Labor force surveys, Statistics Sweden.

Figure 4.2 Temporary work as percent of total wage and salary employment and unemployment as percent of the labor force, 1987-2002 (seasonally adjusted quarterly data).

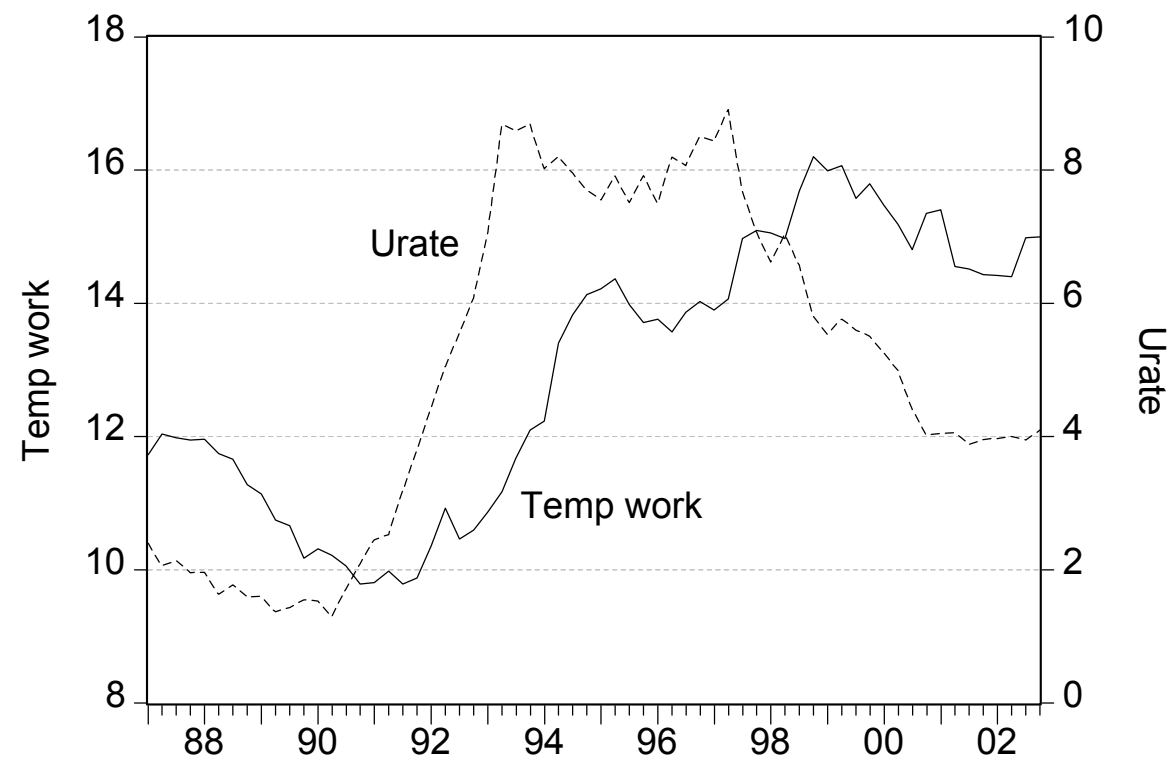

Source: Labor force surveys, Statistics Sweden. 


\section{Temporary Work Agencies}

Employment intermediaries in the form of temporary agency work have been on the rise in most OECD countries in recent years. The workers concerned are employed in temporary work agencies (TWA) but assigned to work at a different user firm. It has been estimated that over two million workers in EU were employed in the TWA sector in the late 1990s (Storrie, 2002).

Since 1993, Sweden has one of the most liberal TWA regulations in the OECD. Most EU countries have some specific regulations concerning TWAs. Sweden, on the other hand, has essentially no special regulation. The TWA sector was virtually illegal and therefore nonexistent in Sweden before 1993. It is still small and accounts for less than one percent of the labor force (Andersson and Wadensjö, 2002). The sector is presumably considerably more important in terms of new hires. In Sweden, fixed-term contracts account for an overwhelming majority of new hires even though the share of the stock of employees is only around 15 percent. Analogously, it is likely that TWAs are much more quantitatively important for the flows than for the stocks.

There is so far only scanty empirical knowledge about the TWA sector and its labor market impact. It is plausible that TWAs can have favorable impact on overall recruitments by effectively reducing hiring costs. These effects may conceivably be stronger in an economy with stringent employment protection, i.e., high costs of hiring and firing. Emerging evidence from the U.S. suggests that TWAs can serve to screen prospective employees and thereby perhaps improve matching between workers and vacancies. Some simple regressions run by Katz and Krueger (1999) on U.S. state data suggest that wage inflation has been lower in states with a higher initial TWA share. Taken at face values, their estimates would imply that TWAs have contributed to a decline in the NAIRU in the 1990s relative to the 1980s.

In summary, the 1990s have seen notable changes concerning employment contracts in the Swedish labor market. The steep rise in the number of fixed-term contracts appear to be an endogenous response to macroeconomic and possibly also structural (but not well understood) factors; in any event, the increase has little to do with legislative changes. The fast growth of employment intermediaries is clearly due to a major reform in the early 1990s. The growth of fixed-term contracts may have caused some rise in unemployment through more frequent 
worker separations. The growth of the temporary work agencies should have improved matching efficiency. On balance, the total effect on unemployment is probably small.

\subsection{Deregulations in Product Markets}

Standard theory predicts that more competitive product markets are conducive to low unemployment, at least in the long run. More intense competition brings about increased output and employment at given wage costs. It should also foster wage moderation by raising the costs to unions of aggressive wage demands. See Blanchard and Giavazzi (2001) for a comprehensive discussion of short run and long run effects.

The 1990s have seen a general trend towards increased competition in Swedish product markets. The areas of deregulation include public procurement, telecommunications, energy, domestic air-traffic, railway transport and taxi. The share of household consumption that is directed at markets exposed to competitive forces increased between 1991 and 1999 by 7 percentage points (Braunerhjelm et al, 2002). A new competition law has been put in place in 1993 that involved tougher sanctions against non-competitive behavior in product markets. In addition, there has been some rise in competitive pressure arising from Sweden's participation in the European economic integration.

Nicoletti et al (2001) have tried to obtain quantitative estimates of the impact of product market regulations on employment by exploiting information on regulatory reform in OECD countries since the late 1970s. Taken at face values, the estimated effects are quantitatively nontrivial. The results for Sweden would imply that regulatory reform over the 1980s and the 1990s have added 2 percentage points to private sector employment relative to population. ${ }^{23}$ Although this estimate should be taken with at least the usual caution, it points in the "right" direction. It is likely that the regulatory reforms in conjunction with intensified international competition have led to some decline in the Swedish NAIRU.

\section{5 Unemployment Insurance}

The fiscal crisis in the early 1990s induced a sequence of decisions to make the UI system less generous and less expensive. The statutory replacement rate was reduced from 90 to 80 percent the $1^{\text {st }}$ of July 1993 and was further reduced to 75 percent from the $1^{\text {st }}$ of January

\footnotetext{
${ }^{23}$ See OECD Employment Outlook 2002, chapter 5. A caveat is that the results also indicate that product market regulations are less harmful in countries with corporatist wage setting regimes.
} 
1996. It is noteworthy that the main motivation for benefit cuts was the need to exercise fiscal restraint. Concerns about possible adverse incentive effects have not played a major role in the Swedish political debate. In fact, in the wake of fiscal consolidation in the late 1990s, a decision was taken to raise the UI replacement rate to 80 percent from September 1997.

The average effective replacement rate depends also on the benefit ceiling. The ceiling was reduced in 1993 and remained constant in nominal terms until 1998 when a rise was undertaken. However, the increase was small and did not even restore the nominal value of the pre-1993 ceiling. The next adjustments of the ceiling came in 2001 and 2002. The combination of a slightly declining benefit ceiling and continuous nominal wage growth led to a substantial fall in replacement rates for workers with above-average earnings. Figure 4.3 shows replacement rates by wage percentiles of the overall wage distribution. For workers in the first quartile (P25) of the wage distribution, the fall in replacement rates between 1992 and 2000 amounts to 10 percentage points (which is equal to the statutory change since these workers are well below the ceiling). The fall amounts to 20 percentage points for a medianwage worker (P50) and to 25 percentage points or more for workers in the top quarter (P75) of the wage distribution.

Figure 4.3 Replacement rates in unemployment insurance by wage percentiles.

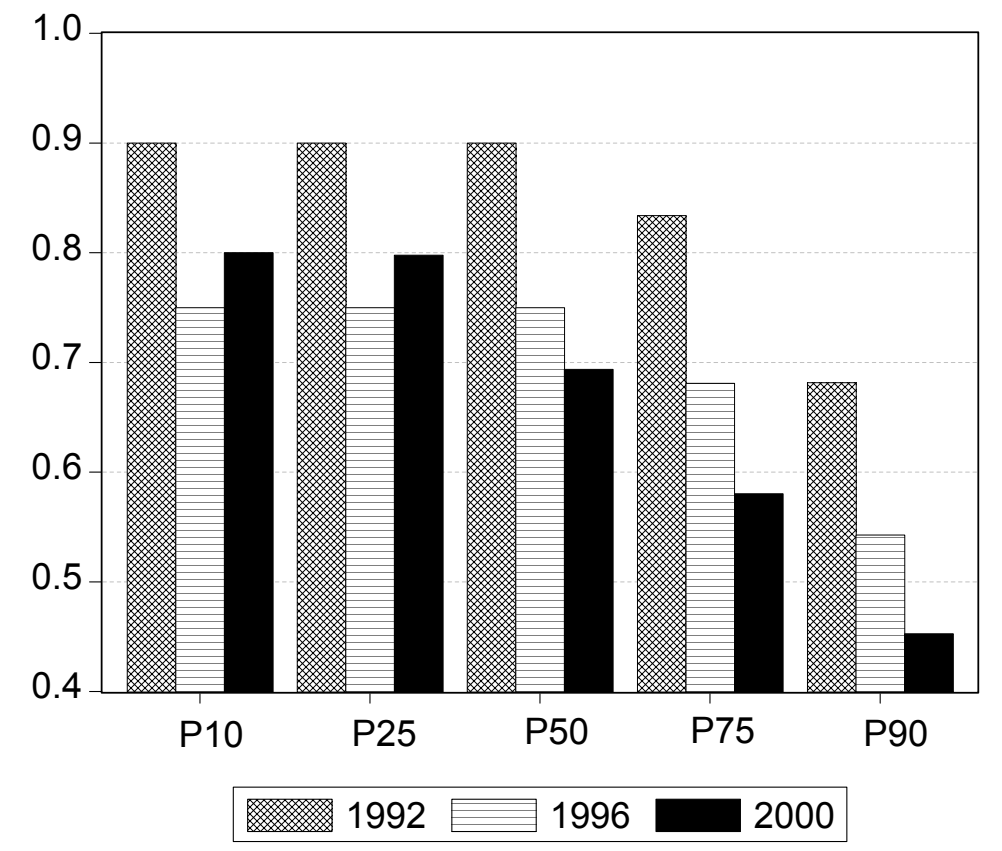

Source: Own computations using benefit data from the insurance unit of the National Labour Market Board and wage data from the statistical yearbooks of wages and salaries from Statistics Sweden. 
The overall generosity of the UI system has thus fallen since the early 1990s. Although the (prospective) replacement rates have declined substantially for a typical employed worker, they have fallen less for a typical unemployed individual since the latter have generally below-average (previous and prospective) wages. Data from the 1990s indicate that some 20 percent of the workers that entered insured unemployment received less than the statutory replacement rate (Carling et al, 2001).

Available empirical studies indicate that the benefit cuts of 1993 and 1996 led to a fall in the duration of unemployment. Harkman (1997) examined the 1993 reform and found that it had some positive effect on job finding. He also identified a fairly large positive effect on the exit rate to nonparticipation. Carling et al (2001) investigated the effects of the 1996 benefit cut and estimated a positive job finding effect but found no effect on labor force exits.

Received theory suggests that higher replacement rates should raise wage pressure so there is a presumption that the benefit cuts have caused wage moderation. Unfortunately, it has been notoriously difficult to pin down precisely how UI benefits affect wage determination. Two recent studies report somewhat conflicting results. Forslund and Kolm (2000) find some evidence supporting the conventional hypothesis but the results are sensitive to the exact specifications. Nymoen and Rødseth (2003) cannot confirm that replacement rates matter for Swedish wage setting.

A major UI reform was undertaken in 2001. A benefit recipient can restrict job search to his or her occupation and local labor market during the first 100 days of unemployment. After this period, the search area has to widen. In some sense, these new rules represented a move towards increased generosity since the previous system involved no rights to restrict search. In practice, however, it may well have been the case that such "search area" rules were used also before 2001. The 2001 reform also set the maximum UI period to 300 days for all eligible unemployed, irrespective of age (compared to 450 days for older workers in the previous system). Furthermore, participation in a labor market program should no longer serve as qualification for UI. The rules for sanctioning an unemployed individual who does not pursue active search were also changed in 2001. The previous system entailed fairly harsh punishment for failure to meet search requirements (complete withdrawal of benefits for a certain time period). The new system involves milder sanctions (such as a reduction of 
benefits by 25 or 50 percent), the idea being that sanctions should be enforced more frequently.

In summary, the UI system around the year 2000 was less generous than in the early 1990s. There is some evidence that the benefit cuts during the 1990s have reduced the duration of unemployment and presumably therefore also reduced the NAIRU. If these effects were quantitatively important, they should also reveal themselves in aggregate data on job findings and possibly as a leftward shift of the "inflow-constant" Beveridge curve. However, such effects do not speak loudly in the data. Some simple transition rate models indicate reasonably stable relationships between labor market tightness and job finding over the period since the late 1980s. This suggests that whatever effects there have been, they have probably been quantitatively modest.

\subsection{Active Labor Market Policy}

The labor market recovery of the late 1990s was associated with a decline in the volume of active labor market programs. In 1997, ALMPs stood at 4.7 percent relative to the labor force; by 2001 , the ALMP rate had fallen to 2.5 percent.

The 1990s have seen not only an increase in various ALMP measures but also a marked growth in the number of evaluation studies. Is there any evidence that the intensive use of ALMPs has had beneficial employment effects? By and large, such positive evidence is rather hard to find. There is fairly clear evidence that subsidized employment has had large crowding-out effects. Similar crowding-out effects are not found for training programs. The experiences of youth programs are largely negative: it has been difficult to find positive effects on earnings or employment. ${ }^{24}$

On the positive side, there is some evidence that ALMPs have encouraged labor force participation, which may have facilitated the employment rebound in the late 1990s. Johansson (2001) examined panel data on labor market programs and labor force participation for Swedish municipalities over the period 1986-1998. She found that a rise in program

\footnotetext{
${ }^{24}$ Calmfors et al (2001) present a comprehensive survey of Swedish experiences of active labor market policies. Larsson (2002) presents evaluations of youth programs. Fredriksson and Johansson (2003) examine how program participation affects reemployment rates among prime-aged individuals. Martin and Grubb (2001) provide evidence for a number of OECD countries.
} 
activity led to a non-trivial increase in labor force participation although it is unclear to which extent this reflects active job search as opposed to "benefit seeking".

All in all, it is plausible that the intensive use of ALMPs has resulted in lower open unemployment than otherwise would have prevailed. It is less clear, however, whether the policies have had much positive effect on total employment.

\subsection{Other Suspects}

It remains to briefly consider other factors that may have contributed to the fall in unemployment. Among the possible suspects, the tax system is not a plausible one since there have been few changes in the system. However, there have been changes in demographics, public employment and absenteeism that most likely have reinforced the decline in unemployment in the late 1990s.

Concerning demographic changes, Figure 3.6 above has provided a picture of how changes in the age composition of the population have affected nonemployment over the period 19872001. The declining relative size of youth cohorts has produced a "mechanical" decline in nonemployment in the late 1990s and early 2000s that amounts to around one percentage point. The conventional presumption would be that this demographic development has caused some decline in the NAIRU. However, recent work on demographics and search cautions against very strong beliefs in the conventional wisdom; cf. Shimer (2001) and Nordström Skans (2002).

The evolution of public sector employment in recent years has also contributed to a fall in (cyclical) unemployment. When fiscal policy became more expansionary, this also affected public sector employment. Between 1997 and 2001, public employment rose by around 40000 persons, corresponding to 0.5 percent of working age population; cf. Figure 3.1.

Finally, consider cyclical absenteeism. As shown in Figure 3.2, absenteeism has risen sharply since the mid-1990s. A mirror image of this development is a marked decline in average work hours among the employed (Figure 3.3). This decline in average work hours should have raised the demand for workers compared to an alternative with constant absenteeism and work hours. This "work sharing" effect is potentially quantitatively important, considering the substantial ( 3 percent) decline in average hours per employed. 


\section{Concluding Remarks}

The paper has argued that adverse macroeconomic shocks were mainly responsible for the steep rise in Swedish unemployment in the early 1990s. These shocks had both domestic and foreign origins, where the domestic shocks were the results of major policy failures. The timing of financial liberalization and the "tax reform of the century" was certainly not well designed. The consumption boom that emerged in the late 1980s, involving gradually rising inflation as well as falling unemployment, could have been curtailed by fiscal policy. However, fiscal policy was generally too lax and the hands of monetary policy were tied to the defense of the fixed exchange rate. When macroeconomic policy finally took a firm antiinflationary stand, the economy was already edging towards recession. The depth of the recession was reinforced by the international recession of the early 1990s and by increasing real interest rates.

The strong recovery in the late 1990s has moderated fears that the high unemployment should become persistent. In many respects, the labor market rebound from 1997 and onwards indicate that the Swedish labor market has worked reasonably well. Wage inflation has been largely under control, job finding rates have risen uniformly across unemployed individuals with short and very long time in joblessness, and there is little evidence of worsening matching problems.

Several policy changes may have contributed to some decline in the NAIRU over the 1990s. Unemployment benefits have become less generous, the labor market has been opened for employment intermediaries, and regulatory reforms have enhanced competition in product markets. Moreover, innovations in collective bargaining arrangements have facilitated informal coordination of wage negotiations.

Although there are grounds for a generally positive rating of recent Swedish labor market performance, there are also grounds for a less sanguine verdict. The problems become evident as one redirects attention from unemployment to nonemployment. The overall nonemployment rate among prime-aged individuals increased from 8.4 percent in 1990 to 17.4 percent in 1995 and had declined to 15.4 percent in 2001. This development of nonemployment is mirrored by a sharp fall in labor force participation during the early 1990s. Some of the rise in nonparticipation is probably "natural" and socially beneficial. For 
example, it reflects in part more enrollment in higher education. However, there is also a trend towards more inactivity in the form of long-term sickness and early retirement. In fact, the overall labor force participation rate is roughly the same in 2001 as in 1995, and lower for prime-aged individuals. To the extent that there are important interaction effects between shocks and institutions, as discussed by Blanchard and Wolfers (2000), they have probably mainly operated by reducing participation as a result of generous schemes favoring nonparticipation.

Swedish labor market policies have traditionally focused on open unemployment and been less concerned with employment. There are signs that policies are changing towards more emphasis on employment. ${ }^{25}$ This is a welcome reorientation, not the least in light of future demographic developments. This reorientation towards enhancing employment needs to address several routes to inactivity, notably sick absence and early retirements. A unified approach to unemployment, employment and nonparticipation also needs to take seriously the evidence that suggests that incentives for non-work activities arise in rules pertaining to early retirement and sickness insurance as much as in rules for unemployment insurance.

\section{References}

Agell, J., Englund, P. and Södersten, J. (1995). Svensk skattepolitik i teori och praktik (Swedish Tax Policy in Theory and Practice). Report to the Tax Evaluation Committtee, SOU 1995:104. Fritzes.

Akerlof, G., Dickens W. and Perry, G. (1996). 'The Macroeconomics of Low Inflation.' Brookings Papers on Economic Activity, No 1, 1-59.

Akerlof, G., Dickens W. and Perry, G. (2000). 'Near-Rational Wage and Price Setting and the Long Run Phillips Curve. Brookings Papers on Economic Activity, No 1, 1-44.

Andersson, F. (1999). 'Job Flows in Swedish Manufacturing 1972-1996.' Working Paper 1999:4, Institute for Labour Market Policy Evaluation (IFAU).

Andersson, P. and Wadensjö, E. (2002). 'Vem arbetar i bemanningsbranschen?' Arbetsmarknad \& Arbetsliv 8, 257-271.

Algan, Y., Cahuc, P. and Zylberberg, A. (2002). 'Public Employment and Labour Market Performance.' Economic Policy, April, 9-65.

\footnotetext{
${ }^{25}$ The government's "employment goal" states that 80 percent of the population aged 20-64 should be employed in 2004 .
} 
Apel, M. and Jansson, P. (1999). 'System Estimates of Potential Output and the NAIRU.' Empirical Economics 24, 373-388.

Arai, M. and Heyman, F. (2002). 'The Impact of Temporary Contracts on Gross Job and Worker Flows.' In F. Heyman: Empirical Studies of Wages, Firm Performance and Job Turnover, PhD Dissertation, Stockholm School of Economics.

Assarsson, B. and Jansson, P. (1998). 'Unemployment Persistence: The Case of Sweden' Applied Economics Letters 5, 25-29.

Björklund, A. and Holmlund, B. (1991). 'The Economics of Unemployment Insurance: The Case of Sweden.' In A. Björklund, R. Haveman, R. Hollister and B. Holmlund: Labour Market Policy and Unemployment Insurance, Oxford University Press.

Blanchard, O. and Wolfers, J. (2000). 'The Role of Shocks and Institutions in the Rise of European Unemployment: The Aggregate Evidence.' Economic Journal 110, 1-33.

Blanchard, O. and Giavazzi, F. (2002). 'Macroeconomic Effects of Regulation and Deregulation in Goods and Labor Markets.' Manuscript, Department of Economics, MIT.

Braunerhjelm, P. (ed.) (2002). Gränslös konkurrens. SNS Förlag.

Calmfors, L., Forslund, A. and Hemström, M. (2001). 'Does Active Labour Market Policy Work? Lessons from the Swedish Experiences.' Swedish Economic Policy Review 8, 61-124.

Carling, K., Edin, P-A., Harkman, A. and Holmlund, B. (1996). 'Unemployment Duration, Unemployment Benefits and Labor Market Programs in Sweden.' Journal of Public Economics 59, 313-34.

Carling, K., Holmlund, B. and Vejsiu, A. (2001). 'Do Benefit Cuts Boost Job Finding? Swedish Evidence from the 1990s.' Economic Journal 111, 766-790.

Clark, K. and Summers, L. (1979). 'Labor Market Dynamics and Unemployment: A Reconsideration.' Brookings Papers on Economic Activity, No 1, 13-60

Edin, P.-A. and Holmlund, B. (1991). 'Unemployment, Vacancies and Labour Market Programmes: Swedish Evidence.' In F. Padoa-Schioppa, ed., Mismatch and Labour Mobility, Cambridge University Press.

Edin, P.-A. and Holmund, B. (1994). Arbetslösheten och arbetsmarknadens funktionssätt (Unemployment and the Functioning of the Labor Market). Report to the Swedish Long Term Survey 1994 (LU 94). Fritzes.

Edin, P-A. and Holmlund, B. (1997). 'Sectoral Structural Change and the State of the Labor Market in Sweden.' In H. Siebert, ed., Structural Change and Labor Market Flexibility, Mohr Siebeck.

Elmeskov, J., Martin J. P. and Scarpetta, S. (1998). 'Key Lessons for Labour Market Reforms: Evidence from OECD Countries' Experiences.' Swedish Economic Policy Review 5, 205-252. 
Elvander, N. (2002). 'The New Swedish Regime for Collective Bargaining and Conflict Resolution: A Comparative Perspective'. European Journal of Industrial Relations 8, 197 216.

Englund, P. (1998). 'Var avregleringen av kreditmarknaden en efterfrågechock?' (Was the Credit Market Deregulation a Demand Shock?). Ekonomisk Debatt 26, 367-380.

Fehr, E. and Goette, L. (2000). 'Robustness and Real Consequences of Nominal Wage Rigidity.' Working Paper No. 44, Institute for Empirical Research in Economics, University of Zurich.

Forslund, A. (1995). 'Unemployment - Is Sweden Still Different?' Swedish Economic Policy Review 2, 25-58.

Forslund, A. and Kolm A.-S. (2000). 'Active Labour Market Policies and Real Wage Determination.' Working Paper 2002:7, Institute for Labour Market Policy Evaluation (IFAU).

Fredriksson, P. and Johansson, P. (2003). 'Employment, Mobility, and Active Labor Market Programs.' Working Paper 2003:5, Department of Economics, Uppsala University.

Harkman, A. (1997). 'Arbetslöshetsersättning och arbetslöshetstid - vilken effekt hade sänkningen från 90 till 80 procents ersättningsnivå?' (Unemployment Compensation and Unemployment Duration - What Was the Effect of the Cut in the Replacement Rate from 90 to 80 Percent?). In A. Harkman, F. Jansson, K. Källberg and L. Öhrn, Arbetslöshetsersättningen och arbetsmarknadens funktionssätt. The National Labour Market Board.

Holden, S. and Nymoen, R. (2002). 'Measuring Structural Unemployment: NAWRU Estimates in the Nordic Countries.' Scandinavian Journal of Economics 104, 87-104.

Holmlund, B. (1993a). 'Arbetslöshetskrisen - konjunkturfenomen eller systemfel?' (The Unemployment Crisis - Business Cycle Effects or Structural Factors?). In SOU 1993:16: Nya villkor för ekonomi och politik (Bilagedel 1). Allmänna Förlaget.

Holmlund, B. (1993b). 'Wage Setting in Private and Public Sectors in a Model with Endogenous Government Behavior.' European Journal of Political Economy 9, 149-162.

Holmlund, B. (1997). 'Macroeconomic Implications of Cash Limits in the Public Sector.' Economica 64, 49-62.

Holmlund, B. and Kolm, A.-S. (1995). 'Progressive Taxation, Wage Setting and Unemployment: Theory and Swedish Evidence.' Swedish Economic Policy Review 2, 423460.

Holmlund, B. and Vejsiu, A. (2001). 'Labor Market Flows in Boom and Slump: Sweden 1987-2000.' In A. Vejsiu: Essays on Labor Market Dynamics. Economic Studies 56, Department of Economics, Uppsala University.

Holmlund, B. and Storrie, D. (2002). 'Temporary Jobs in Turbulent Times: The Swedish Experience.’ Economic Journal 112, F245-F269. 
Honkapohja, S. and Koskela, E. (1999). 'The Economic Crisis of the 1990s in Finland.' Economic Policy, October, 401-436.

Hunt, J. (1999). 'Has Work Sharing Worked in Germany?' Quarterly Journal of Economics $114,117-148$.

Johansson, K. (2001). 'Do Labor Market Programs Affect Labor Force Participation?' Swedish Economic Policy Review 8, 215-234.

Johansson, S., Lundborg, P. and Zetterberg, J. (1999). Massarbetslöshetens karaktär och vägarna till full sysselsättning (Mass Unemployment and Paths to Full Employment). Trade Union Institute for Economic Research (FIEF).

Katz, L. and Krueger, A. (1999). 'The High-Pressure U.S. Labor Market of the 1990s.' Brookings Papers on Economic Activity, No 1, 1-65.

Kjellberg, A. (2001). Fackliga organisationer och medlemmar i dagens Sverige (Trade Unions and Union Members in Sweden). Arkiv förlag.

Konjunkturinstitutet (2002). Konjunkturläget (December). Konjunkturinstitutet.

Korpi, T. and Levin, H. (2001). 'Precarious Footing: Temporary Employment as a Stepping Stone out of Unemployment in Sweden.' Work, Employment and Society 15, 127-148.

Larsson, L. (2002). Evaluating Social Programs: Active Labor Market Policies and Social Insurance. $\mathrm{PhD}$ thesis, Department of Economics, Uppsala University.

Layard, R., Nickell, S. and Jackman, R. (1991). Unemployment-Macroeconomic Performance and the Labour Market. Oxford University Press.

Lindblad, H. (1997). 'Persistence in Swedish Unemployment Rates.' Working Paper, Department of Economics, Stockholm University.

Lundborg, P. and Sacklén, H. (2002). 'Is There a Long Run Unemployment-Inflation Tradeoff in Sweden?' Working Paper No 173, Trade Union Institute for Economic Research (FIEF).

Martin, J. P. and Grubb D. (2001). 'What Works and for Whom: A Review of OECD Countries' Experiences with Active Labour Market Policies.' Swedish Economic Policy Review 8, 9-56.

Nelander, S. and Goding, I. (2003). 'Myter och vanföreställningar.' Manuscript, LO.

Nickell, S. and Quintini, G. (2001). 'Nominal Wage Rigidity and the Rate of Inflation.' Discussion Paper, Centre for Economic Perfomance, London School of Economics.

Nickell, S. and van Ours, J. (2000). 'The Netherlands and the United Kingdom: a European Unemployment Miracle?' Economic Policy April, 137-180. 
Nicoletti, G., Bassanini, A., Ernst, E., Jean, S., Santiago, P. and Swaim, P. (2001). 'Product and Labour Markets Interactions in OECD Countries.' Economics Department Working Paper No. 312, OECD.

Nordström Skans, O. (2002). Labour Market Effects of Working Time Reductions and Demographic Changes. PhD thesis, Department of Economics, Uppsala University.

Nymoen, R. and Rødseth, A. (2003). 'Explaining Unemployment: Some Lessons from Nordic Wage Formation.’ Labour Economics 10, 1-29.

OECD (2001, 2002). Employment Outlook, OECD.

Ohlsson, H. (2002). 'The Swedish Industrial Agreement.' Manuscript, Department of Economics, Göteborg University.

Persson, H. (1999). Essays on Labour Demand and Career Mobility. PhD thesis, Swedish Institute for Social Research, Stockholm University.

Pissarides, C. A. (2000). Equilibrium Unemployment Theory. MIT Press.

Rantala, A. (2001). 'Does Monetary Union Reduce Employment?' Bank of Finland Discussion Papers, 2001/7.

Shimer, R. (2001). 'The Impact of Young Workers on the Aggregate Labor Market.' Quarterly Journal of Economics 116, 969-1007.

SOU 1996:51. Grundläggande drag i en ny arbetslöshetsförsäkring (Basic Features of a New Unemployment Insurance System). Fritzes.

Storrie, D. (2002). Temporary Agency Work in the European Union. European Foundation for the Improvement of Living and Working Conditions, Dublin.

Wohlin, L. (1998). 'Bankkrisens upprinnelse' (The Origin of the Banking Crisis). Ekonomisk Debatt 26, 21-30. 


\title{
CESifo Working Paper Series
}

\author{
(for full list see www.cesifo.de)
}

852 Gregory D. Hess, The Economic Welfare Cost of Conflict: An Empirical Assessment, February 2003

853 Douglas J. Cumming and Jeffrey G. MacIntosh, Comparative Venture Capital Governance. Private versus Labour Sponsored Venture Capital Funds, February 2003

854 Eckhard Janeba and John Douglas Wilson, Decentralization and International Tax Competition, February 2003

855 Tapio Palokangas, Capital Accumulation and Employment Cycles in a Model of Creative Destruction, February 2003

856 Brendan Walsh, When Unemployment Disappears: Ireland in the 1990s, February 2003

857 Luis H. R. Alvarez and Erkki Koskela, A General Approach to the Stochastic Rotation Problem with Amenity Valuation, February 2003

858 Christian Schultz, Strategic Campaigns and Redistributive Politics, February 2003

859 Ernst Fehr and Joseph Henrich, Is Strong Reciprocity a Maladaptation? On the Evolutionary Foundations of Human Altruism, February 2003

860 Haizhou Huang, Dalia Marin, and Chenggang Xu, Financial Crisis, Economic Recovery and Banking Development in Former Soviet Union Economies, February 2003

861 Pedro Cardoso and Bernard M.S. van Praag, How Sustainable Are Old-age Pensions in a Shrinking Population with Endogenous Labour Supply?, February 2003

862 Volker Meier, Efficient Transfer of Aging Provisions in Private Health Insurance, February 2003

863 Edward Castronova, Theory of the Avatar, February 2003

864 Robert S. Chirinko, Hans van Ees, Harry Garretsen, and Elmer Sterken, Investor Protections and Concentrated Ownership: Assessing Corporate Control Mechanisms in the Netherlands, February 2003

865 Bernard M.S. van Praag and Pedro Cardoso, The Mix Between Pay-as-you-go and Funded Pensions and what Demography has to do with it, February 2003

866 Ernst Fehr, Urs Fischbacher, Bernhard von Rosenbladt, Jürgen Schupp, and Gert G. Wagner, A Nation-Wide Laboratory. Examining Trust and Trustworthiness by Integrating Behavioral Experiments into Representative Survey, February 2003 
867 Frank Heinemann, The Inflationary Impact of Wage Indexation, February 2003

868 Eytan Sheshinski, Bounded Rationality and Socially Optimal Limits on Choice in a Self-Selection Model, February 2003

869 M. Hashem Pesaran, Estimation and Inference in Large Heterogenous Panels with Cross Section Dependence, February 2003

870 Luis H. R. Alvarez and Erkki Koskela, On the Tree-Cutting Problem under Interest Rate and Forest Value Uncertainty, February 2003

871 Norbert Berthold and Rainer Fehn, Unemployment in Germany: Reasons and Remedies, February 2003

872 Clemens Fuest, Bernd Huber, and Philipp Tilleßen, Tax Policy and Entrepreneurship in the Presence of Asymmetric Information in Capital Markets, February 2003

873 Eytan Sheshinski, Optimum and Risk-Class Pricing of Annuities, February 2003

874 Willi Leibfritz, Paul O'Brien and Jean-Christophe Dumont, Effects of Immigration on Labour Markets and Government Budgets - An Overview, February 2003

875 M. Hashem Pesaran and Allan Timmermann, How Costly is it to Ignore Breaks when Forecasting the Direction of a Time Series?, February 2003

876 Thorvaldur Gylfason and Gylfi Zoega, Education, Social Equality and Economic Growth: A View of the Landscape, February 2003

877 Robin Boadway and Jean-François Tremblay, Public Economics and Startup Entrepreneurs, February 2003

878 Erkki Koskela and Roope Uusitalo, The Un-Intended Convergence: How the Finnish Unemployment Reached the European Level, February 2003

879 Robert Fenge and Volker Meier, Pensions and Fertility Incentives, February 2003

880 Eytan Sheshinski, Note on Income Taxation and Occupational Choice, February 2003

881 A B Atkinson, Income Inequality in OECD Countries: Data and Explanations, February 2003

882 Thomas Gehrig and Rune Stenbacka, Venture Cycles: Theory and Evidence, February 2003

883 Ralf Becker and Thomas Hellmann, The Genesis of Venture Capital - Lessons from the German Experience, March 2003

884 Eytan Sheshinski, Note on the Optimum Pricing of Annuities, March 2003

885 Paul De Grauwe and Magdalena Polan, Globalisation and Social Spending, March 2003 
886 F. van der Ploeg, Do Social Policies Harm Employment and Growth?, March 2003

887 Mirjam van Praag, Initial Capital Constraints Hinder Entrepreneurial Venture Performance: An empirical analysis, March 2003

888 Bernard Steunenberg, Coordinating Sectoral Policymaking: Searching for Countervailing Mechanisms in the EU Legislative Process, March 2003

889 Eytan Sheshinski, Optimum Delayed Retirement Credit, March 2003

890 Frederick van der Ploeg, Rolling Back the Public Sector - Differential effects on employment, investment and growth, March 2003

891 Paul De Grauwe and Marc-Alexandre Sénégas, Monetary Policy in EMU when the Transmission is Asymmetric and Uncertain, March 2003

892 Steffen Huck and Kai A. Konrad, Strategic Trade Policy and the Home Bias in Firm Ownership Structure, March 2003

893 Harry Flam, Turkey and the EU: Politics and Economics of Accession, March 2003

894 Mathias Hoffmann and Ronald MacDonald, A Re-examination of the Link between Real Exchange Rates and Real Interest Rate Differentials, March 2003

895 Badi H. Baltagi, Espen Bratberg, and Tor Helge Holmås, A Panel Data Study of Physicians' Labor Supply: The Case of Norway, March 2003

896 Dennis C. Mueller, Rights and Citizenship in the European Union, March 2003

897 Jeremy Edwards, Gains from Trade in Tax Revenue and the Efficiency Case for Trade Taxes, March 2003

898 Rainer Fehn and Thomas Fuchs, Capital Market Institutions and Venture Capital: Do They Affect Unemployment and Labour Demand?, March 2003

899 Ronald MacDonald and Cezary Wójcik, Catching Up: The Role of Demand, Supply and Regulated Price Effects on the Real Exchange Rates of Four Accession Countries, March 2003

900 R. Selten, M. Schreckenberg, T. Pitz, T. Chmura, and S. Kube, Experiments and Simulations on Day-to-Day Route Choice-Behaviour, April 2003

901 Stergios Skaperdas, Restraining the Genuine Homo Economicus: Why the Economy Cannot be Divorced from its Governance, April 2003

902 Yin-Wong Cheung, Menzie D. Chinn, and Antonio Garcia Pascual, What Do We Know about Recent Exchange Rate Models? In-Sample Fit and Out-of-Sample Performance Evaluated, April 2003

903 Mika Widgrén, Enlargements and the Principles of Designing EU - Decision-Making Procedures, April 2003 
904 Phornchanok Cumperayot, Dusting off the Perception of Risk and Returns in FOREX Markets, April 2003

905 Kai A Konrad, Inverse Campaigning, April 2003

906 Lars P. Feld and Stefan Voigt, Economic Growth and Judicial Independence: Cross Country Evidence Using a New Set of Indicators, April 2003

907 Giuseppe Bertola and Pietro Garibaldi, The Structure and History of Italian Unemployment, April 2003

908 Robert A.J. Dur and Otto H. Swank, Producing and Manipulating Information, April 2003

909 Christian Gollier, Collective Risk-Taking Decisions with Heterogeneous Beliefs, April 2003

910 Alexander F Wagner, Mathias Dufour, and Friedrich Schneider, Satisfaction not Guaranteed - Institutions and Satisfaction with Democracy in Western Europe, April 2003

911 Ngo Van Long, Raymond Riezman, and Antoine Soubeyran, Trade, Wage Gaps, and Specific Human Capital Accumulation, April 2003

912 Andrea Goldstein, Privatization in Italy 1993-2002: Goals, Institutions, Outcomes, and Outstanding Issues, April 2003

913 Rajshri Jayaraman and Mandar Oak, The Signaling Role of Municipal Currencies in Local Development, April 2003

914 Volker Grossmann, Managerial Job Assignment and Imperfect Competition in Asymmetric Equilibrium, April 2003

915 Christian Gollier and Richard Zeckhauser, Collective Investment Decision Making with Heterogeneous Time Preferences, April 2003

916 Thomas Moutos and William Scarth, Some Macroeconomic Consequences of Basic Income and Employment Subsidies, April 2003

917 Jan C. van Ours, Has the Dutch Miracle Come to an End?, April 2003

918 Bertil Holmlund, The Rise and Fall of Swedish Unemployment, April 2003 